\title{
REVIEW
}

\section{Mouse models for inherited endocrine and metabolic disorders}

\author{
Siân E Piret and Rajesh V Thakker \\ Academic Endocrine Unit, Oxford Centre for Diabetes, Endocrinology and Metabolism, Churchill Hospital, University of Oxford, Headington, \\ Oxford OX3 7LJ, UK \\ (Correspondence should be addressed to R V Thakker; Email: rajesh.thakker@ndm.ox.ac.uk)
}

\begin{abstract}
In vivo models represent important resources for investigating the physiological mechanisms underlying endocrine and metabolic disorders, and for pre-clinical translational studies that may include the assessments of new treatments. In the study of endocrine diseases, which affect multiple organs, in vivo models provide specific advantages over in vitro models, which are limited to investigation of isolated systems. In recent years, the mouse has become the popular choice for developing such in vivo mammalian models, as it has a genome that shares $\sim 85 \%$ identity to that of man, and has many physiological systems that are similar to those in man. Moreover, methods have been developed to alter the expression of genes in the mouse, thereby generating models for human diseases, which may be due to loss- or gainof-function mutations. The methods used to generate mutations in the mouse genome include: chemical
\end{abstract}

mutagenesis; conventional, conditional and inducible knockout models; knockin models and transgenic models, and these strategies are often complementary. This review describes some of the different strategies that are utilised for generating mouse models. In addition, some mouse models that have been successfully generated by these methods for some human hereditary endocrine and metabolic disorders are reviewed. In particular, the mouse models generated for parathyroid disorders, which include: the multiple endocrine neoplasias; hyperparathyroidism-jaw tumour syndrome; disorders of the calcium-sensing receptor and forms of inherited hypoparathyroidism are discussed. The advances that have been made in our understanding of the mechanisms of these human diseases by investigations of these mouse models are described.

Journal of Endocrinology (2011) 211, 211-230

\section{Introduction}

In vivo models are required for investigating the physiological mechanisms underlying endocrine and metabolic disorders, and for pre-clinical translational studies and assessments of new treatments. Such in vivo models have advantages over in vitro cell culture methods, which are important for functional and molecular investigations, but are nevertheless isolated systems that are outside the context of the whole organism. Thus, in vivo models are of particular importance for the study of multi-system disorders, such as endocrine diseases, that affect multiple tissues. In recent years, the mouse has increasingly become the popular choice for developing such in vivo mammalian models, as it has many physiological systems that are similar to those in man. In addition, the coding regions of mouse and human genomes share $\sim 85 \%$ identity (Waterston et al. 2002) and development of gene targeting methods in the mouse has facilitated the generation of mouse models for human disorders by mutagenic, transgenic and targeted approaches. Furthermore, the small size of mice, coupled with their ability to reproduce rapidly with a short generation time, yields many practical advantages for studying genetic disorders, as well as the effects of different diets and environments. Finally, the availability of inbred mouse strains helps to minimise the variations in phenotype that may occur from genetic modifiers; however, generating the same disease model in different strains enables inter-strain differences in phenotype to be studied as well as identifying the influence of genetic modifiers, which may also contribute to differential phenotypes in man. This review will focus on the main strategies that have been used for generating mouse models (Tables 1 and 2), with an emphasis on describing some of the models that are of relevance to inherited endocrine and metabolic disorders that affect parathyroid gland function, namely: multiple endocrine neoplasia (MEN) type 1 (MEN1); MEN type 2 (MEN2); MEN1like syndrome, MEN4; hyperparathyroidism-jaw tumour syndrome (HPT-JT); disorders of the calcium-sensing receptor (CaSR) and familial forms of hypoparathyroidism (Tables 3 and 4). 
Table 1 Methods resulting in induction of mutations

Example

Method

Spontaneous

Radiation

Chemical

Molecular biological Phex
Hypophosphataemic rickets (Hyp) mouse due to mutation of

Gyro (Gy) mouse, which has hypophosphataemic rickets and hypercalciuria, due to deletion of Phex and spermine synthase genes on the $X$ chromosome

Nuf mouse, which has autosomal dominant hypocalcaemia with cataracts due to an activating CaSR mutation, induced by an alkylating agent, isopropyl methanesulfonate (iPMS), which is mutagenic to testicular and epididymal sperm $\mathrm{DNA}^{\mathrm{a}}$

Deletion of an allele (knockout), e.g. HPT-JT; introduction of point mutation (knockin), e.g. MEN2; transgenic that overexpresses a gene, e.g. MEN2
References

Beck et al. (1997) and Strom et al. (1997)

Strom et al. (1997), Lorenz et al. (1998) and Meyer et al. (1998)

Hough et al. (2004)

Sweetser et al. (1999), Smith-Hicks et al. (2000) and Wang et al. (2008)

Phex, phosphate-regulating gene with homology to endopeptidases on the $\mathrm{X}$ chromosome.

${ }^{a} \mathrm{~N}$-ethyl- $\mathrm{N}$-nitrosourea (ENU) is another alkylating agent that can be used.

\section{Methods used for generating in vivo mouse models}

\section{Non-targeted strategies}

Spontaneous mutations in mice may result in benign phenotypes such as variable coat colours, or in disorders that have similarities to diseases in man, e.g. the hyperphosphataemia $(H y p)$ mouse, which is representative of X-linked hypophosphataemic rickets in man (Tenenhouse 1999). Such spontaneous mutations occur at very low frequencies, and techniques that increase the rate of mutation induction in the mouse genome by non-targeted (random) and targeted strategies have been developed (Tables 1 and 2). An early example is provided by irradiation, which generated the $G y$ mouse, a second model for X-linked hypophosphataemia (Tenenhouse 1999). Recently, chemical mutagens such as isopropyl methanesulfonate (iPMS), which was used to generate the Nuf mouse model with an activating CaSR mutation, and $N$-ethyl- $N$-nitrosourea (ENU), have been used in large-scale mutagenesis programmes. ENU, which is the most potent mutagen in mice, is an alkylating agent that primarily introduces point mutations via transfer of the ENU alkyl group to the DNA base followed by mispairing and subsequent base pair substitution during the next round of DNA replication (Acevedo-Arozena et al. 2008; Fig. 1A). Intraperitoneal injections of ENU to male mice are estimated to yield one mutation per $1-1.5 \mathrm{Mbp}$ of sperm DNA (Acevedo-Arozena et al. 2008) allowing the mutations to be inherited (Fig. 1B). ENU mutagenesis programmes utilise two complementary approaches, which are phenotype- and genotype-driven screens. In phenotype-driven screens, offspring of mutagenised mice are assessed for phenotypic variances, by a panel of morphological, biochemical or behavioural tests, in a 'hypothesis-generating' strategy, which may elucidate new genes, pathways and mechanisms for a disease phenotype (Acevedo-Arozena et al. 2008; Fig. 1B). By establishing appropriate matings, these phenotype-driven screens can be used to investigate for dominant or recessive phenotypes. Genotype-driven screens, in which mutations in a gene of interest are sought, are 'hypothesis-driven' and are feasible by available parallel archives of DNA and sperm samples from mutagenised male mice (Fig. 1B). The archived DNA samples from the mutagenised male mice are used to search for the mutations in the gene of interest, and once mutations are found in the mouse DNA, then the sperm sample for the male mouse harbouring the mutation is used for IVF to establish progeny with the mutation (AcevedoArozena et al. 2008). It is estimated that the probability of finding three or more mutant alleles in an archive of $>5000$ DNA samples is $>90 \%$ (Coghill et al. 2002), thereby enabling the gene-driven approach to be used to generate an 'allelic series' of mutations within one gene, which may therefore yield insights into genotype-phenotype correlations in the gene and disease of interest (Quwailid et al. 2004).

ENU mutations more frequently result in missense mutations $(>80 \%)$ that may generate hypo- and hypermorphs, although occasionally nonsense and frameshift mutations $(<10 \%)$ generating knockout models may also be obtained (Barbaric et al. 2007). However, a more reliable method for generating non-targeted knockout models on a large scale is by the use of insertional mutagenesis, utilising gene traps (Collins et al. 2007a,b). Gene trap vectors usually consist of a reporter gene, either with or without a promoter, and a strong splice acceptor site, which causes any upstream exons to splice directly to the gene trap (Stanford et al. 2001; Fig. 1C). The vector is electroporated or retrovirally infected into embryonic stem (ES) cells, after which it randomly inserts into the genome. Mutagenised ES cells are then reintroduced into developing blastocysts to generate chimaeric mice, from which germline mutant mice can be bred (Fig. 2). A recent refinement of the gene trap strategy is targeted trapping, in which the vector also contains regions homologous to the targeted gene, thereby facilitating the deletion of a specific gene (Friedel et al. 2005, Collins et al. 2007b). 
Table 2 Some methods, with their advantages and disadvantages, for generating mouse models

\begin{tabular}{|c|c|c|c|c|}
\hline & Method & Type of mutation & Advantages & Disadvantages \\
\hline \multirow[t]{3}{*}{$\begin{array}{l}\text { Non-targeted } \\
\text { (random) }\end{array}$} & Spontaneous & $\begin{array}{l}\text { Point mutations, small } \\
\text { deletions, chromosomal } \\
\text { rearrangements }\end{array}$ & $\begin{array}{l}\text { Visible phenotype, no } \\
\text { manipulation of genome }\end{array}$ & Very low frequency \\
\hline & Radiation & $\begin{array}{l}\text { Deletions, inversions, } \\
\text { translocations, complex } \\
\text { rearrangements }\end{array}$ & $\begin{array}{l}\text { Easier mapping due to large } \\
\text { rearrangements }\end{array}$ & $\begin{array}{l}\text { Multiple genes may be } \\
\text { affected }\end{array}$ \\
\hline & $\begin{array}{l}\text { Molecular biological - Gene } \\
\text { trap }\end{array}$ & Knockout & $\begin{array}{l}\text { Easy to map disrupted gene; } \\
\text { can include reporter gene }\end{array}$ & Unpredictable phenotypes \\
\hline \multirow[t]{5}{*}{ Targeted $^{\mathrm{a}}$} & 'Targeted trapping' & Knockout & High targeting frequency & $\begin{array}{l}\text { Gene must be expressed in } \\
\text { ES cells }\end{array}$ \\
\hline & Knockout & Loss-of-function & & \\
\hline & Inducible & $\begin{array}{l}\text { Disruption of gene at time } \\
\text { of choice }\end{array}$ & $\begin{array}{l}\text { Can mimic somatic loss- } \\
\text { of-function; can overcome } \\
\text { embryonic lethality of } \\
\text { knockout }\end{array}$ & Less than $100 \%$ knockout \\
\hline & Knockin & $\begin{array}{l}\text { Mutation of choice including } \\
\text { toxic gain-of-function }\end{array}$ & $\begin{array}{l}\text { Introduction of specific } \\
\text { mutation }\end{array}$ & Labour intensive; expensive \\
\hline & Transgenic & $\begin{array}{l}\text { Activating or dominant } \\
\text { mutations; can also inject } \\
\text { shRNA for RNAi }\end{array}$ & $\begin{array}{l}\text { Introduction of specific } \\
\text { mutation or shRNA of } \\
\text { interest }\end{array}$ & $\begin{array}{l}\text { Random insertion into } \\
\text { genome; transgenes often } \\
\text { overexpressed }\end{array}$ \\
\hline
\end{tabular}

ENU, N-ethyl-N-nitrosourea; shRNA, short hairpin RNA; RNAi, RNA inhibition; ES, embryonic stem.

${ }^{a}$ All the targeted methods use molecular biological mutagenesis (Table 1). Table compiled from Stanford et al. (2001), Friedel et al. (2005), Hickman-Davis \& Davis (2006), Acevedo-Arozena et al. (2008), Hacking (2008), Nguyen \& Xu (2008), Fisher et al. (2009), Hall et al. (2009) and Haruyama et al. (2009).

\section{Targeted strategies}

A specific loss-of-function (i.e. knockout) of the gene of interest in the germline is generated to yield conventional targeted knockout models, as follows. A targeting construct is assembled, containing two 'arms' of sequence homologous to the gene of interest, which flank a positive selection cassette such as the Escherichia coli neomycin phosphotransferase $\left(\mathrm{Neo}^{\mathrm{R}}\right.$ ) gene (Fig. 3A). Integration of the $\mathrm{Neo}^{\mathrm{R}}$ gene (and therefore the targeting construct) into the ES cell genome, allows these ES cells to survive antibiotic treatment, thereby allowing selection of the ES cells that have been successfully targeted by the homologous recombination. Furthermore, replacement of an exon or exons by the $\mathrm{Neo}^{\mathrm{R}}$ cassette results in its disruption, i.e. 'knockout' (Fig. 3A). To further facilitate the selection of ES cells that have undergone successful targeting by homologous recombination, a negative selection cassette, such as the herpes simplex virus thymidine kinase (TK) gene, may also be used. The TK gene cassette is placed at one end of the homologous region of the targeting construct, such that if homologous recombination occurs, then the TK cassette is lost (Fig. 3A), but if non-homologous recombination occurs, then the TK cassette is retained. ES cells containing the TK cassette consistent with nonhomologous recombination, will not undergo cell division when a thymidine analogue is added to the growth medium, as the thymidine analogue will be incorporated into the DNA by the TK, and thereby disrupt cell division and hence select out these ES cells. In contrast, the ES cells that have undergone homologous recombination will not have the TK cassette and will therefore not have disrupted cell division due to incorporation of the thymidine analogue, and as a result will proliferate. These correctly targeted ES cells are then used to generate chimaeric mice (Fig. 2), which are then bred with wild-type mice to yield mice who have a germline transmission of the disrupted allele, and hence are 'knockout' mice. Owing to the germline transmission, these mice will have one copy of the disrupted allele in all of their cells, and crossbreeding of these heterozygous knockout mice can then yield homozygous knockout mice, which will have a disruption of both alleles of the gene in all of their cells. These 'conventional' knockout models have proved to be very useful in studies of human diseases, although their use may be limited if the disruption of the gene in a critical organ 


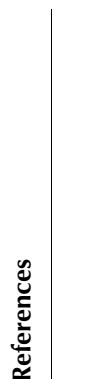

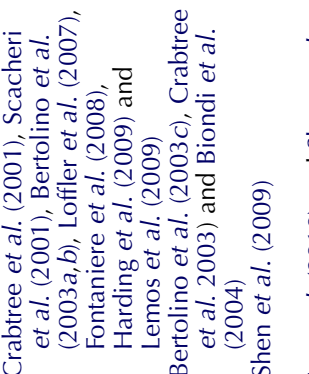
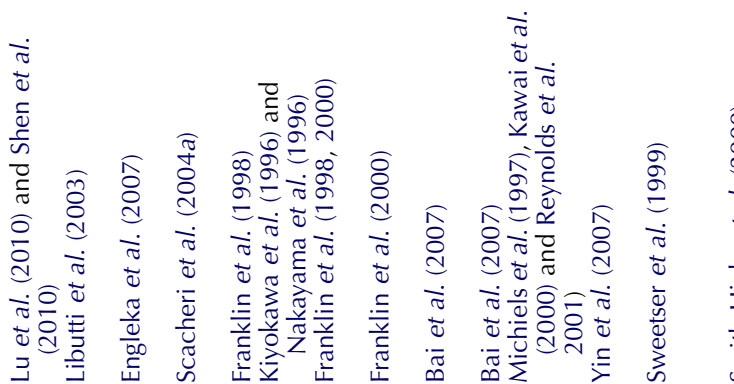

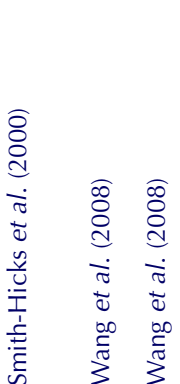
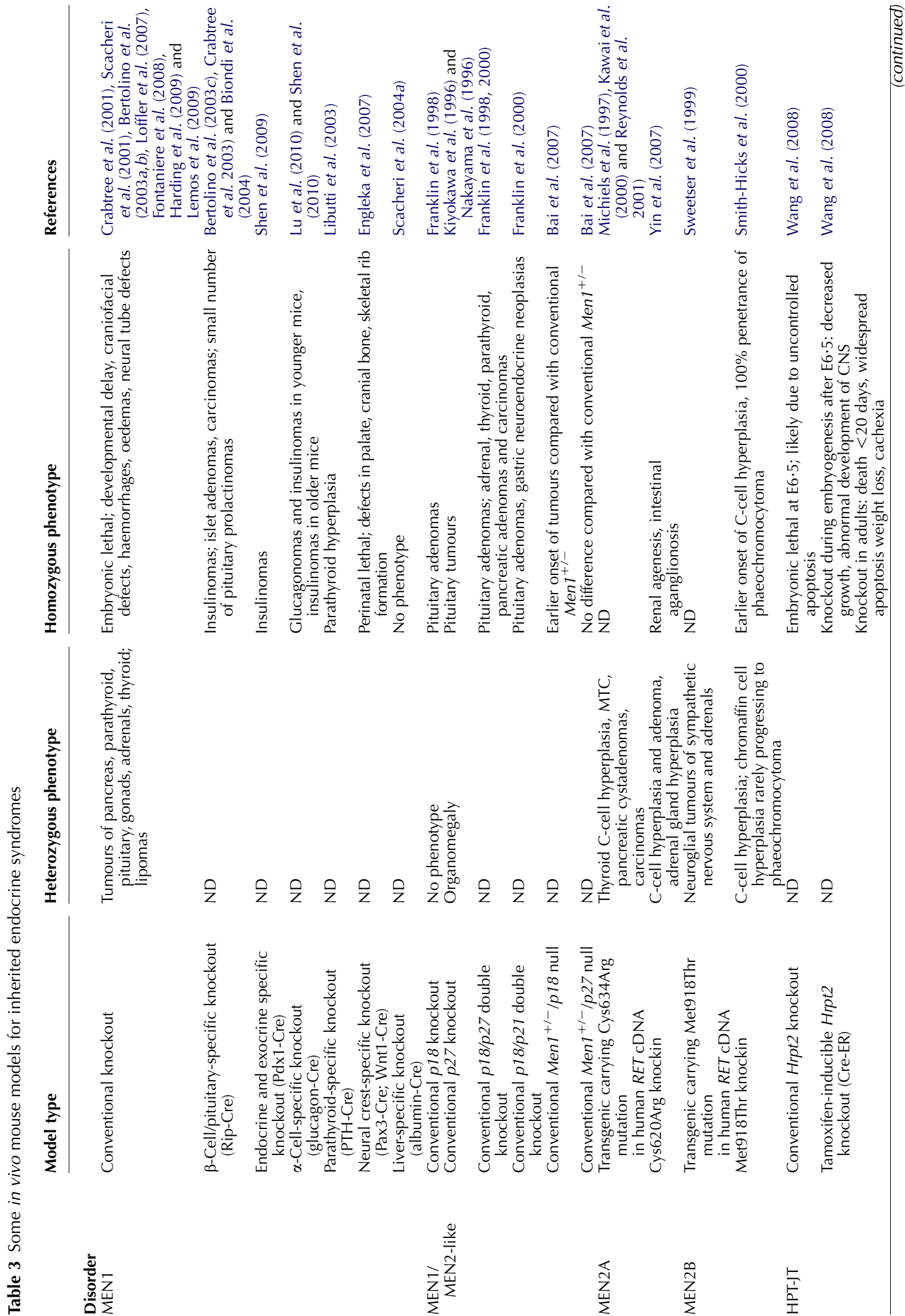

Journal of Endocrinology (2011) 211, 211-230
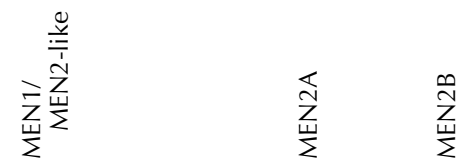

卢 

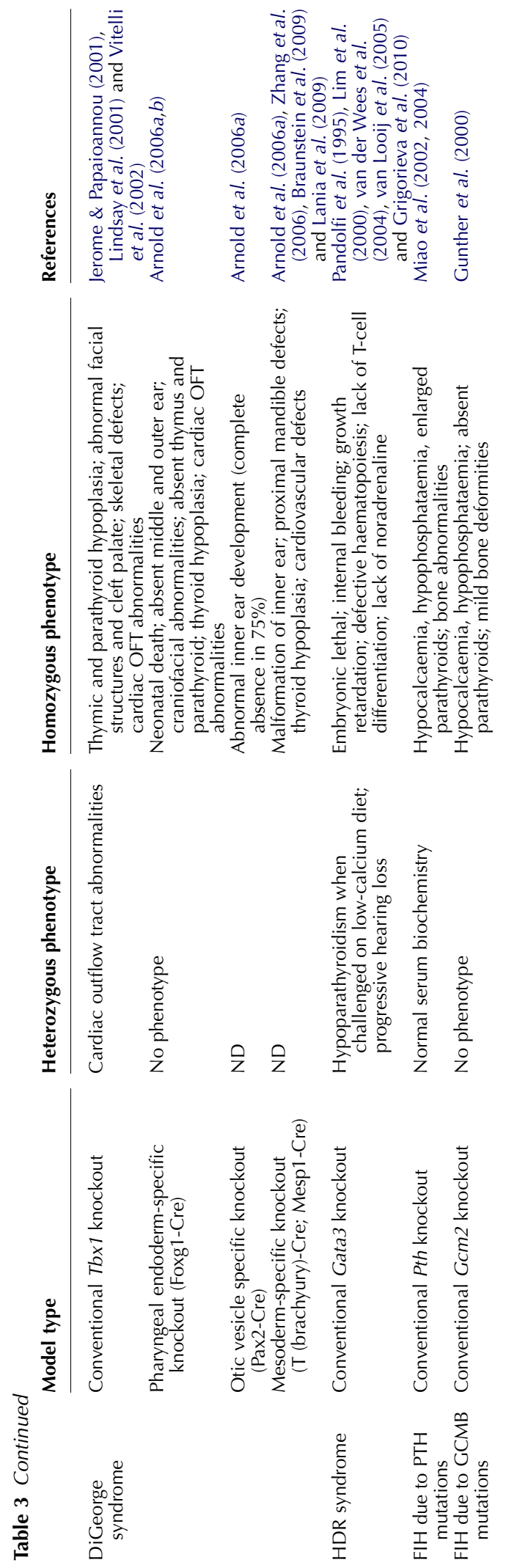

www.endocrinology-journals.org results in early death, e.g. at any embryonic stage. To overcome such limitations, it may be useful to generate tissue(i.e. conditional knockout) or time-specific (i.e. inducible knockout) models. This is achieved by refining the gene trap and 'conventional' knockout strategies by the addition of LoxP or flippase (FLP) recombinase target (FRT) sites in the targeting vector (Fig. 3B). LoxP and FRT sites are short DNA sequences, which are recognised and acted upon by Cre recombinase or FLP enzymes, respectively, and when inserted to flank the genomic region of interest, will result in either excision or inversion of the DNA encompassed by the LoxP or FRT sequences, depending on whether the two sequences are in the same orientation (Fig. 3B), or opposite orientations, respectively. Thus, the insertion of the LoxP and FRT sequences gives scope for several variations on the knockout mouse, including tissue- (conditional) and time-specific (inducible) knockouts (Table 2). Thus, if mice containing alleles in which the exon containing the start codon is encompassed by LoxP sites (floxed) or FRT sites (flirted), are crossed with transgenic mice expressing Cre or FLP under the control of tissue-specific promoters (e.g. the parathyroid hormone (PTH) gene promoter for parathyroid expression), the gene of interest can be knocked out in a specific tissue (Fig. 3B). Inducible models utilise a fusion protein, such as a modified ligand-binding domain of the oestrogen receptor fused to the Cre or FLP gene, which on administration of tamoxifen, translocates to the nucleus to excise the floxed allele(s), thereby allowing the gene to be knocked out at the desired time, which may be either during embryonic or neonatal development, or in adult life (Fisher et al. 2009). These conditional and inducible models have proved particularly useful in the study of tumourigenesis, to overcome the embryonic lethality that often results when tumour suppressor genes are deleted. Furthermore, the conditional and inducible strategies can be combined to generate inducible, tissue-specific models, which mimic the somatic loss of heterozygosity (LOH) of tumour suppressor genes that may trigger tumourigenesis in specific tissues (Fisher et al. 2009).

Such knockout mice have been very valuable for the study of physiological functions of proteins and the elucidation of disease mechanisms. However, knockout models are not always the most appropriate, especially if the human disease being studied is not due to a loss-of-function or null allele for the gene. Indeed, the majority of human diseases are unlikely to be due to null alleles, but are instead associated with point mutations, which may result in a constitutively active protein, dominant-negative effects or a toxic gain-of-function, as illustrated by rearranged during translocation (RET) mutations in MEN2 (see below). Thus, to generate appropriate models for these diseases, one needs to introduce the specific mutation into the mouse genome, and this may be achieved by targeted knockin or transgenic approaches (Tables 1 and 2). The generation of targeted knockin models utilises a similar approach to that described earlier for targeted knockout models, with the exception that a targeting vector 
Table 4 Mouse models for hypercalcaemic and hypocalcaemic disorders due to calcium-sensing receptor (CaSR) mutations

\begin{tabular}{|c|c|c|c|}
\hline & Heterozygous phenotype & Homozygous phenotype & References \\
\hline \multicolumn{4}{|l|}{ Model type } \\
\hline \multicolumn{4}{|l|}{ Loss-of-function } \\
\hline Conventional knockout $\left(\mathrm{Casr}^{-1-}\right)$ & $\begin{array}{l}\text { Hypercalcaemia, hypocalciuria, } \\
\text { elevated serum PTH }\end{array}$ & $\begin{array}{l}\text { Severe hypercalcaemia, high serum } \\
\text { PTH, parathyroid hyperplasia, } \\
\text { bone abnormalities, neonatal death }\end{array}$ & $\begin{array}{l}\text { Ho et al. (1995), Kovacs } \\
\text { et al. (1998) and } \\
\text { Garner et al. (2001) }\end{array}$ \\
\hline $\begin{array}{l}\text { Parathyroid-specific knockout } \\
\text { (PT-KO) }\end{array}$ & $\begin{array}{l}\text { Hypercalciuria, hypercalcaemia, } \\
\text { mild hyperparathyroidism }\end{array}$ & $\begin{array}{l}\text { Severe hyperparathyroidism, hyper- } \\
\text { calciuria, hypercalciuria, skeletal } \\
\text { undermineralisation, neonatal death }\end{array}$ & Chang et al. (2008) \\
\hline $\begin{array}{l}\text { Osteoblast-specific knockout } \\
(\mathrm{COL}-\mathrm{KO})\end{array}$ & No phenotype & $\begin{array}{l}\text { Undermineralisation of bone, multiple } \\
\text { fractures }\end{array}$ & Chang et al. (2008) \\
\hline $\begin{array}{l}\text { Inducible chondrocyte-specific } \\
\text { knockout (Tam-Cart-KO) }\end{array}$ & ND & Short bones & Chang et al. (2008) \\
\hline \multicolumn{4}{|l|}{ Gain-of-function } \\
\hline iPMS mutant (Nuf), L723Q & $\begin{array}{l}\text { Hypocalcaemia, hyperphospha- } \\
\text { taemia, low plasma PTH, ecto- } \\
\text { pic renal calcification, cataracts }\end{array}$ & $\begin{array}{l}\text { Hypocalcaemia, hyperphosphataemia, } \\
\text { low plasma PTH, widespread ectopic } \\
\text { calcification, cataracts }\end{array}$ & Hough et al. (2004) \\
\hline
\end{tabular}

PTH, parathyroid hormone; ND, not determined; iPMS, isopropyl methanesulfonate.

that carries the desired mutation needs to be specifically generated (Fig. 3C). In addition, any selection cassette that is used is normally floxed and placed in an intron so that it can be excised and cause minimal effects on gene expression (Hacking 2008). The generation of transgenic models utilises a targeting construct which usually contains the cDNA carrying the mutation, together with an appropriate promoter and poly(A) sequence, which is injected into the pronucleus of fertilised mouse eggs (Haruyama et al. 2009). The transgene then undergoes random insertion into the genome, and several copies are often inserted together, which generates an overexpression model. These different strategies for generating mouse models of human diseases have greatly facilitated studies of complex inherited endocrine and metabolic syndromes that have investigated mechanisms and treatments, which would not be easily feasible in man. In addition, the development of new technologies, such as the ability to mediate deletion of genes in single cells rather than the majority of cells within a tissue, as with the Cre system, or the ability to combine several mutations within the same cells, will further advance our understanding of the mechanisms of endocrine tumourigenesis, which may involve multiple mutations.

\section{Multiple endocrine neoplasia type 1}

MEN1 is an autosomal dominant disease characterised by the combined occurrence of parathyroid, pancreatic islet and anterior pituitary tumours (Trump et al. 1996). Some patients may also develop adrenocortical adenomas, lipomas and carcinoids (Trump et al. 1996). The MEN1 gene is located on chromosome 11q13 (Larsson et al. 1988, Friedman et al. 1989, Thakker et al. 1989, Chandrasekharappa et al. 1997, Lemmens et al. 1997), and more than 1300 MEN1 mutations, which are likely loss-of-function, have been reported
(Lemos \& Thakker 2008). MEN1 encodes a ubiquitously expressed 610 amino acid protein, menin, which is predominantly localised to the nucleus (Guru et al. 1998, Huang et al. 1999). Studies of menin and its interacting proteins have revealed roles in transcriptional regulation, genome stability, cell division and cell cycle control (reviewed in Thakker (2010)). The mouse Men 1 gene, which is located on chromosome 19, shares $89 \%$ identity to human MEN1 (Bassett et al. 1999). This has enabled mouse models to be established, and since the majority of MEN1 mutations lead to loss-of-function of menin, studies have concentrated on knockout models (Table 3).

\section{Conventional Men1 knockout models}

Five conventional Men1 knockout models have been generated to date, by deletion of various combinations of exons 1-8 (Crabtree et al. 2001, Scacheri et al. 2001, Bertolino et al. 2003a,b, Loffler et al. 2007, Harding et al. 2009, Lemos et al. 2009). One of these models was reported to be embryonic lethal in the heterozygous state; however, this was likely due to an aberrant transcript from the antisense strand of the phosphoglycerate kinase 1-neomycin cassette that was used to replace exons 2-4 in the model (Scacheri et al. 2001). The remaining four models show many similarities as well as some important differences. Heterozygous $\left(\right.$ Men $\left.1^{+/-}\right)$mice developed multiple tumours in a timedependent manner beginning at around 9-month old, including those of the pancreas, anterior pituitary, parathyroids and adrenal tumours, as well as lipomas, which are all found in MEN1 patients. In addition, Men $1^{+/-}$mice developed gonadal tumours in both male and female mice, which are not found in MEN1 patients. LOH of menin was also demonstrated in these tumours (Crabtree et al. 2001, Bertolino et al. 2003b, Loffler et al. 2007, Harding et al. 2009), consistent with the MEN1 gene being a tumour suppressor. 
A

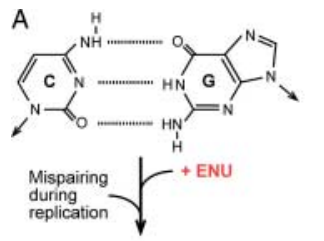

B

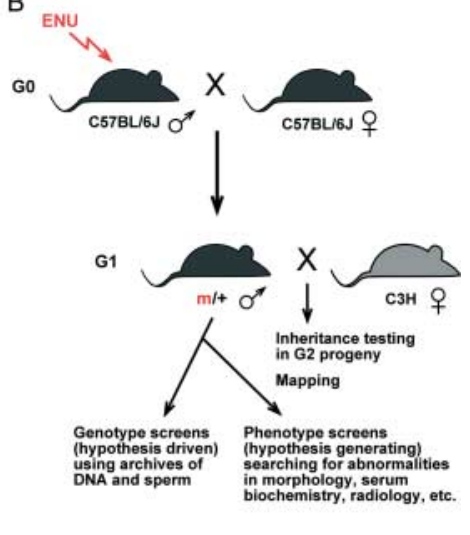

C Gene trap

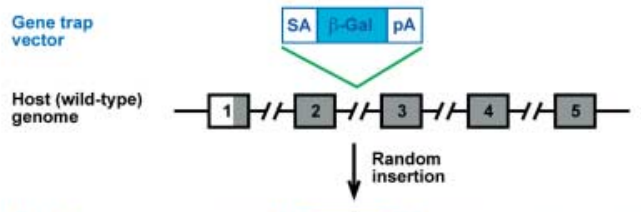

Mutant

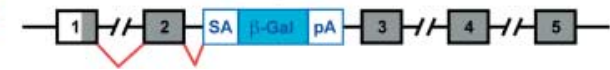

Figure 1 Methods for non-targeted (random) mutagenesis. (A) Chemical mutagenesis using $N$-ethyl- $N$-nitrosourea (ENU). ENU is an alkylating agent that transfers its ethyl group to one of a number of reactive sites on DNA nucleotides, including the $\mathrm{O}^{6}$ of guanine as shown. Modification of guanine with the ethyl group (red) to produce $\mathrm{O}^{6}$-ethylGuanine $(\mathrm{O}-\mathrm{eG})$, causes mispairing during DNA replication, e.g. at spermatogenesis, and during subsequent replication a mutation is introduced. (B) ENU-mutagenised G0 male mice, harbouring induced mutations in their sperm DNA, are mated with wild-type females of the same strain to generate G1 mice. G1 males are examined for phenotypic abnormalities (i.e. the phenotype-driven screens). Males with phenotypic abnormalities of interest are then mated with wild-type females to facilitate inheritance testing and genetic mapping in affected offspring (G2) to identify the mutation causing the phenotypic abnormality. DNA and sperm from all the G1 males are also archived to facilitate genotype-driven screens. $\mathrm{m}$ (in red), mutant allele; + , wild-type allele. (C) Insertion mutagenesis using gene trap vectors. Gene trap vectors consist of a strong splice acceptor (SA), a reporter gene such as $\beta$-galactosidase ( $\beta$-gal) and a poly-adenine tract $(\mathrm{pA})$. The gene trap randomly inserts into the host genome, and during splicing, the splice acceptor is used in preference to the normal genomic splice sites (splicing pattern shown by red lines). Filled boxes denote coding sequences and open boxes denote non-coding sequences.

Interestingly, thyroid tumours, which have been described in MEN1 patients, but considered to be a co-incidental finding due to the high frequency of thyroid nodules in the general population (Thakker 2006), were detected in $\mathrm{Men} 1^{+/-}$ mice, and shown to have loss of menin expression, thereby suggesting that thyroid tumours may be part of the MEN1 syndrome (Crabtree et al. 2001, Bertolino et al. 2003b, Loffler et al. 2007, Harding et al. 2009). A number of the tumours were shown by immunohistological analysis to be insulinomas, glucagonomas, prolactinomas and somatotrophinomas (Crabtree et al. 2001, Bertolino et al. 2003b, Loffler et al. 2007,
Harding et al. 2009). Only one of the models was reported to have adrenocorticotropinomas and one model was reported to have adrenal cortical tumours (Harding et al. 2009) in association with hypercorticosteronaemia; two other models were reported to have increased circulating levels of insulin (Crabtree et al. 2001, Bertolino et al. 2003b); one model had increased serum PTH in a small proportion of mice (Bertolino et al. 2003b) and another model was reported with hypercalcaemia and hypophosphataemia in the context of inappropriately normal PTH levels, consistent with primary hyperparathyroidism (Harding et al. 2009). The reasons for the differences between the various models remain to be elucidated, but may include the different background strains used. Interestingly, one of the studies assessed expression of somatostatin receptor type 2 (SSTR2) and vascular endothelial growth factor A (VEGFA), and found that expression was retained in pancreatic islet tumours and pituitary tumours, indicating that this model may be useful in testing potential new therapies such as newer somatostatin analogues and inhibitors of angiogenesis, which target SSTR2 and VEGFA respectively (Harding et al. 2009).

Homozygous knockout $\left(\operatorname{Men} 1^{-/-}\right)$mice have also been studied, and are reported to be embryonically lethal between embryonic day (E) $10 \cdot 5$ and E14.5, with developmental delay, craniofacial defects, haemorrhages, oedema and neural tube defects (Crabtree et al. 2001, Bertolino et al. 2003a, Lemos et al. 2009), as well as a defect in the developing endocrine pancreas (Fontaniere et al. 2008). This demonstrates previously unknown roles for menin in the development of multiple tissues, which may include regulating the expression of extracellular matrix proteins that are required during organogenesis (Ji et al. 2007). Interestingly, when Men 1 knockout mice were bred onto congenic $129 \mathrm{~S} 6 / \mathrm{SvEv}$ and C57BL/6 strains, Men $1^{-/-}$mice on the $129 \mathrm{~S} 6 / \mathrm{SvEv}$ background demonstrated a significantly earlier lethality than $\mathrm{Men} 1^{-1-}$ on the C57BL/6 background, and displayed different phenotypes, suggesting a role for genetic modifiers in menin-dependent developmental processes (Lemos et al. 2009).

\section{Conditional Men1 knockout models}

To overcome the problem of embryonic lethality in $\mathrm{Men} 1^{-/-}$ mice, several tissue-specific models have been generated (Table 3), which have the added advantage of allowing the study of tumourigenesis in individual organs. Furthermore, rather than requiring a sporadic second hit for tumourigenesis, the Men 1 alleles can be deleted in all animals at the same time, thereby generating a homogenous population to study. Three pancreatic $\beta$-cell-specific Men $1^{-/-}$mouse models have been generated, utilising Cre under the control of the rat insulin promoter (Rip-Cre). These mouse models demonstrated pancreatic islet cell hyperplasia, which commenced at 2 months of age, and led to the formation of insulinomas, which were associated with hypoglycaemia and hyperinsulinaemia (Bertolino et al. 2003c, Crabtree et al. 2003, Biondi 


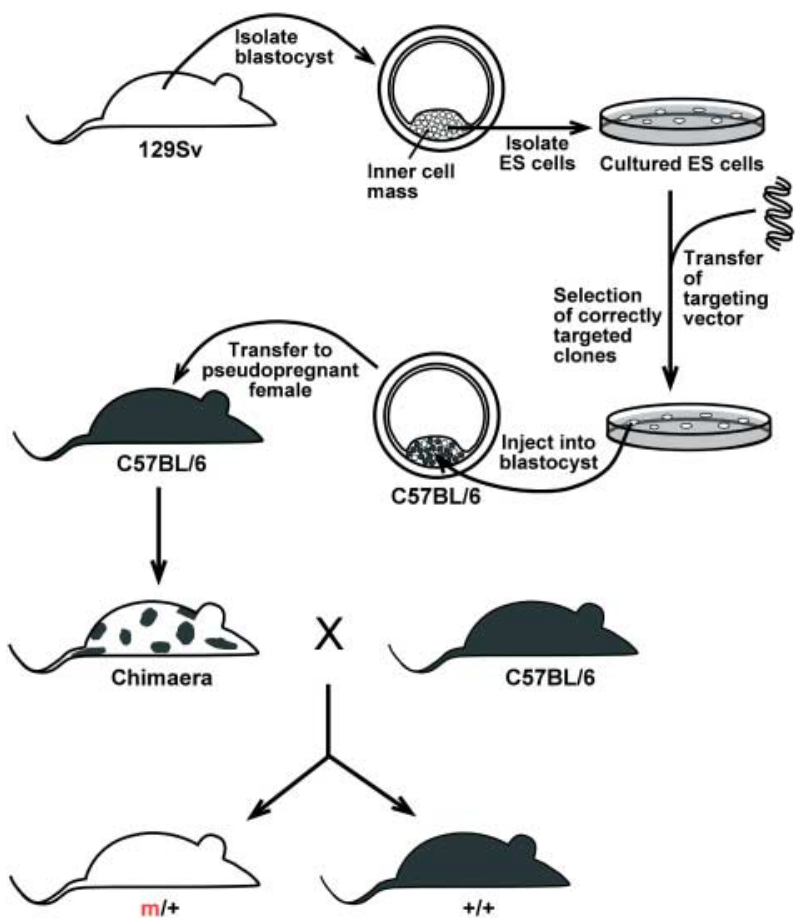

Figure 2 Gene targeting by modification of embryonic stem (ES) cells. Totipotent ES cells are isolated from the inner cell mass of a blastocyst (for example from a 129Sv (shown) or C57BI/6 embryo) and cultured. The targeting vector is transferred to the ES cells, and those in which homologous recombination or integration has been successful are selected. These are injected into the inner cell mass of a blastocyst from a different mouse strain (for example C57BL/6 (shown)), which is transferred to the uterus of a pseudopregnant female. The resulting chimaeric offspring (usually males are selected) are bred with wild type, e.g. C57BL/6 mice (usually females are selected) to achieve germline transmission. $\mathrm{m}$, mutant allele; + , wild-type allele.

et al. 2004). In one of the models, the pancreatic islet cell adenomas progressed to carcinomas, with tumour vascularisation and down-regulation of E-cadherin and $\beta$-catenin (Bertolino et al. 2003c). Tumour development in all of these models stemmed from increased cell proliferation, and interestingly, when different Rip-Cre mouse lines were used with varying expression, a higher expression of Cre was found to result in an earlier tumour formation (Crabtree et al. 2003). Rip-Cre is also expressed in the pituitary, and two of the studies reported prolactinomas in a subset of mice (Crabtree et al. 2003, Biondi et al. 2004). The delay in tumour formation despite the early loss of Men 1 in these models suggests that additional genetic events are likely to be required for tumour formation, and DNA extracted from some tumours demonstrated loss and gain of other chromosomal regions in the pancreatic islet cell and pituitary tumours, supporting this hypothesis (Crabtree et al. 2003). However, other tumours did not have chromosomal alterations, suggesting different mechanisms for tumour formation that may also include nucleotide or epigenetic changes (Scacheri et al. $2004 b$ ). Expression profiling of insulinomas from the mice revealed disturbances in different cellular pathways, which included those of signal transduction, transcription, cell cycle and cell differentiation (Fontaniere et al. 2006). Furthermore, specific transcriptional targets of menin, such as members of the Hox gene family, which had previously been identified in vitro, were also found to be dysregulated, along with other members of the same family (Fontaniere et al. 2006), thereby verifying and extending findings from in vitro studies of menin function. These alterations have subsequently been found to occur also in human MEN1 tumours (Shen et al. 2008). A model in which Men 1 was knocked out in both endocrine and exocrine pancreas by use of pancreatic and duodenal homeobox 1 ( $\mathrm{Pdx} 1)-C r e$, had increased cell proliferation in endocrine but not exocrine pancreatic cells, and developed vascular insulinomas, which were associated with hypoglycaemia and hyperinsulinaemia (Shen et al. 2009). This model is of interest as it may help to elucidate the basis for tumours specifically forming in endocrine organs in MEN1.

Two pancreatic $\alpha$-cell-specific Men $1^{-/-}$models have also been generated, utilising a glucagon-Cre, and these have produced unexpected results. In one model, tumours expressed only glucagon, only insulin, or both glucagon and insulin in 8-month-old mice; in mice older than 12 months, only $5 \%$ of tumours expressed glucagon alone (Lu et al. 2010). However, in another model, only insulinomas developed in mice aged between 13 and 14 months (Shen et al. 2010). These differences may in part be due to transdifferentiation of $\alpha$ - to $\beta$-cells, or to a loss or gain of important paracrine signals which induce existing $\beta$-cells to proliferate. Further studies of these interesting models may yield insights into the less frequent occurrence of glucagonomas, compared with insulinomas, in MEN1.

A parathyroid-specific Men $1^{-/-}$model has also been generated using PTH-Cre, and by the age of 9 months, $>80 \%$ of mice had parathyroid hyperplasia, associated with hypercalcaemia (Libutti et al. 2003). Other tissues were normal, thereby verifying the tissue specificity of this model, and its use in elucidating the pathways of parathyroid tumourigenesis.

Other conditional models have been generated in which tissues that are not usually affected in MEN1 had the Men 1 alleles deleted. These have yielded insights into the in vivo function of menin in these tissues. Thus, knockout of Men 1 in neural crest cells using Pax3-Cre and Wnt1-Cre led to defects in palate, cranial bone and skeletal rib formation and perinatal lethality, thereby demonstrating roles for menin in osteogenesis and palatogenesis (Engleka et al. 2007). The generation of liver-specific null mice using albumin-Cre, which is only weakly expressed during embryogenesis (E19) and expressed fully 1-2 weeks after birth, did not lead to the development of liver tumours, although some mice developed insulinomas, which was attributed to 'leaky' expression of Cre in the pancreas 
(Scacheri et al. 2004a). Further studies of this model may help to elucidate reasons for the tissue specificity of tumour formation in MEN1.

\section{Cyclin-dependent kinase inhibitor knockouts with MEN-like phenotypes}

Cyclin-dependent kinases (CDKs) are cell cycle regulators that phosphorylate members of the retinoblastoma (RB) family and release them from binding to members of the E2F family of transcription factors (Fig. 4), which transcribe genes essential for transition to the DNA synthesis $(\mathrm{S})$ phase of the cell cycle (Lapenna \& Giordano 2009). CDKs function in association with partner cyclins, and the associations of cyclin D with CDK4 and CKD6 are particularly important for the transition to $\mathrm{S}$ phase. All cell cycle components are strictly regulated, and for CDK4/CDK6, this is achieved by members of both the inhibitors of CDK4 (INK4) and CDK interacting protein/kinase inhibitory protein (Cip/Kip) families of CDK inhibitors (CDKIs), which consist of $\mathrm{p} 15^{\text {Ink } 4 \mathrm{a}}, \mathrm{p} 16^{\text {Ink } 4 \mathrm{~b}}$, $\mathrm{p} 18^{\text {Ink } 4 \mathrm{c}}$ and $\mathrm{p} 19^{\mathrm{Ink} 4 \mathrm{~d}}$; and $\mathrm{p} 21^{\text {Cip1/Waf1 }}, \mathrm{p} 27^{\mathrm{Kip} 1}$ and $\mathrm{p} 57^{\mathrm{Kip} 2}$ respectively (Fig. 4). Knockout models of CDKIs have been generated and their MEN-like phenotypes have prompted in vitro studies of the functional interactions between menin and CDKIs. Single knockouts of CDKIs have not generally yielded tumour phenotypes, which are usually found in double knockout models. For example, the $\mathrm{p} 18^{\text {Ink } 4 \mathrm{c}}$ null and $\mathrm{p} 27^{\mathrm{Kip} 1}$ heterozygous and null mice have widespread organomegaly, but only develop tumours of the anterior pituitary (Kiyokawa et al. 1996, Nakayama et al. 1996, Franklin et al. 1998). Similarly, p21 Cip1/Waf1 null mice were originally reported to be free from tumours and developmental defects up to the age of 7 months (Deng et al. 1995); however, analysis of older mice showed tumour formation, although this was not in endocrine tissues (Martin-Caballero et al. 2001). However, in $\mathrm{p} 18^{\mathrm{Ink} 4 \mathrm{c}} / \mathrm{p} 27^{\mathrm{Kip} 1}$ double knockouts, pituitary adenoma development was accelerated (Franklin et al. 1998), and tumours of the adrenal, thyroid, parathyroid and testes developed, as well as pancreatic adenomas and carcinomas (Franklin et al. 2000). Furthermore, multiple tumours involving different organs were often found in the same mouse, thereby resembling MEN1 in man (Franklin et al. 2000). Similarly, p18 ${ }^{\text {Ink } 4 \mathrm{c}} / \mathrm{p} 21^{\text {Cip } 1 / \text { Waf1 }}$ double-null mice have an increased prevalence of pituitary adenomas compared with $\mathrm{p} 18^{\text {Ink4c }}$ null, and most of the double-null mice also developed multifocal gastric neuroendocrine neoplasias, as well as lung tumours (Franklin et al. 2000). The phenotypes of these compound null mice, and their similarities to those observed in MEN1 in man has prompted several in vitro studies exploring the functional relationships between CDKIs and menin. This has revealed that menin and mixed-lineage leukaemia (MLL) family members are recruited to the promoter regions of $\mathrm{p} 18^{\mathrm{Ink} 4 \mathrm{c}}$ and $\mathrm{p} 27^{\mathrm{Kip} 1}$, to activate their transcription (Milne et al. 2005; Fig. 4), which occurs via methylation of histone $\mathrm{H} 3$ at lysine 4 (H3K4 methylation) that is associated with the $\mathrm{p} 18^{\mathrm{Ink} 4 \mathrm{c}}$ and $\mathrm{p} 27^{\mathrm{Kip} 1}$ promoters
(Karnik et al. 2005). Both $\mathrm{p} 18^{\mathrm{Ink} 4 \mathrm{c}}$ and $\mathrm{p} 27^{\mathrm{Kip} 1}$ are downregulated in Men $1^{-1-}$ MEFs (Milne et al. 2005), and H3K4 methylation was found to be markedly reduced or undetected in the islet tumours from Men $1^{+/-}$mice (Karnik et al. 2005).
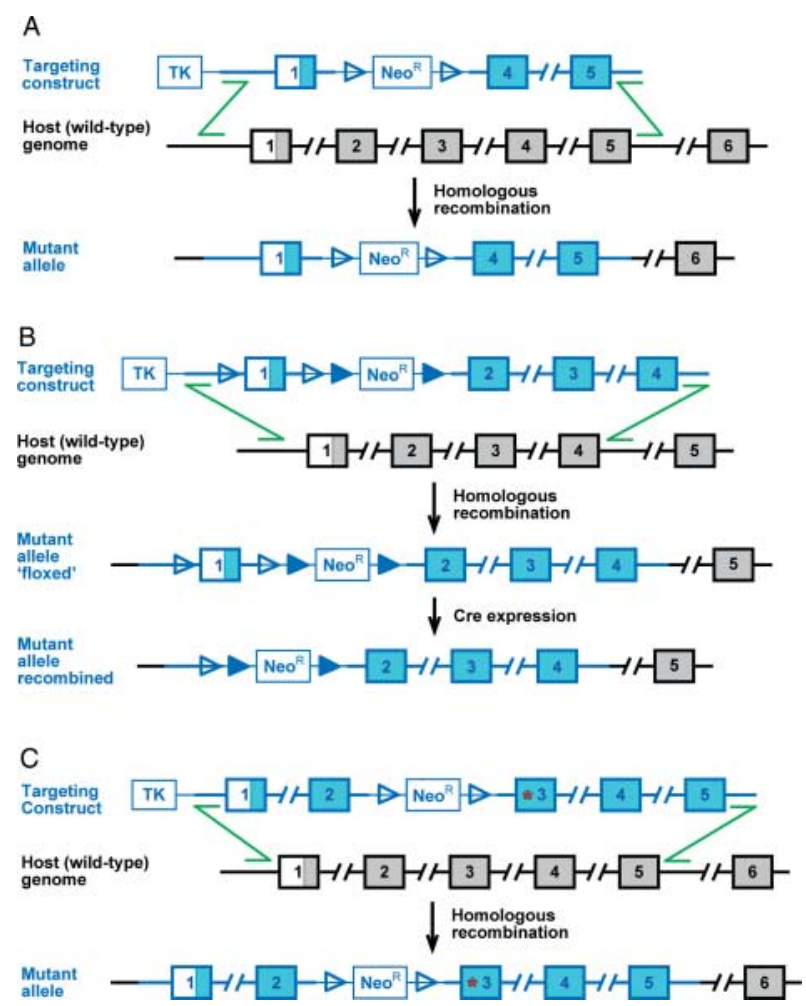

Figure 3 Strategies for targeted mutagenesis in embryonic stem (ES) cells. Targeting vectors (blue) typically consist of two 'arms' of sequence homologous to the target gene flanking a positive selection cassette such as the neomycin phosphotransferase $\left(\mathrm{Neo}^{\mathrm{R}}\right)$ gene, and with a negative selection cassette such as the thymidine kinase (TK) gene at one end of the construct. The $\mathrm{Neo}^{\mathrm{R}}$ cassette is usually flanked by two LoxP sites (open triangles) so that it may be removed by expression of Cre recombinase after homologous recombination (green lines) with the host (wild type) genome (black). When homologous recombination occurs, the negative selection cassette is lost. Thick lines denote sequences derived from genomic DNA, with filled boxes representing coding exons and open boxes representing non-coding exons; thin lines denote sequences derived from vectors. (A) Conventional knockout. In a typical conventional knockout targeting vector, the $\mathrm{Neo}^{\mathrm{R}}$ cassette replaces one or more exons, and is then excised by Cre recombinase after homologous recombination. (B) Conditional or inducible knockout. The $\mathrm{Neo}^{\mathrm{R}}$ cassette may be flanked by flippase (FLP) recombinase target (FRT) sites (filled triangles) to allow removal by expression of FLP. Part of the coding region of the gene is also flanked by LoxP sites (open triangles). Thus, when homozygote mutant mice are crossed with mice expressing Cre in a tissuespecific manner, or mice expressing an inducible Cre, the gene is knocked out within the tissue or upon administration of the inducer. (C) Knockin. A specific mutation is introduced into the targeting vector (red asterisk), usually by site-directed mutagenesis. The $\mathrm{Neo}^{\mathrm{R}}$ cassette is placed in an intron close to the mutation and excised after homologous recombination, either by introduction of Cre recombinase into the ES cells or by breeding mutant mice with mice expressing Cre ubiquitously. 


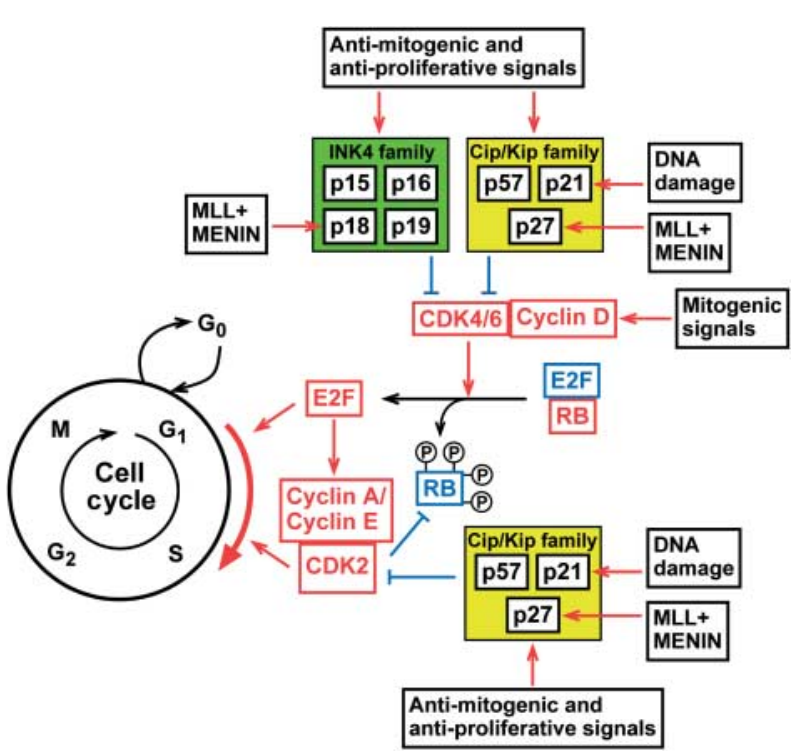

Figure 4 Role of CDKIs in cell cycle progression. The cell cycle consists of five distinct phases. The first growth or gap $\left(\mathrm{G}_{1}\right)$ phase, which entails biosynthesis of key enzymes required for DNA manufacture, precedes the synthesis $(S)$ phase during which DNA is synthesised, which is followed by the second gap $\left(\mathrm{G}_{2}\right)$ phase, during which the microtubules required for the mitosis $(M)$ phase are produced. The resting phase $\left(\mathrm{G}_{0}\right)$ is a post-mitotic phase during which cells are quiescent and non-proliferative. The $G_{1}$ to $S$ phase transition of the cell cycle is tightly regulated by cyclin-dependent kinases (CDKs), their partner cyclins and CDK inhibitors (CDKIs). The $\mathrm{E} 2 \mathrm{~F}$ family of transcription factors is sequestered by members of the retinoblastoma (RB) gene family. CDK4 and CDK6, in conjunction with cyclin D, phosphorylate RB family members, releasing the $\mathrm{E} 2 \mathrm{~F}$ family members to transcribe genes critical for cell cycle progression. CDK4 and CDK6 are inhibited by members of both the inhibitors of CDK4 (INK4) and CDK interacting protein/kinase inhibitory protein (Cip/Kip) family of CDKIs. Targets of the $\mathrm{E} 2 \mathrm{~F}$ transcription factors include cyclin $\mathrm{A}$ and cyclin $\mathrm{E}$ which are required in conjunction with CDK2 late in the $\mathrm{G}_{1}$ phase. CDK2 is inhibited by members of the Cip/Kip family of CDKIs, and also reinforces the inactivation of RB by maintaining its phosphorylation, and completing the transition into the $S$ phase (Lapenna \& Giordano 2009). Mixed-lineage leukaemia (MLL) family members and menin activate transcription of $\mathrm{p} 18^{\operatorname{lnk} 4 \mathrm{C}}$ and $\mathrm{p} 27^{\mathrm{Kip} 1}$ (Milne et al. 2005). Red arrows indicate activation/up-regulation, blue lines indicate inactivation; red boxes/text indicate active proteins and blue boxes/text indicate inactive proteins.

Men $1^{-/-}$MEFs were also found to have loss of the usual $\mathrm{p} 21^{\mathrm{Cip} 1 / \text { Waf1 }}$ up-regulation that occurs in response to DNA damage by mutagens, thereby demonstrating a possible mechanism for the accumulation of secondary mutations in MEN1 tumours (Kottemann \& Bale 2009). Thus, there are functional relationships between menin and CDKIs. In menin-null cells, in vitro studies have shown that menin regulates $\mathrm{p} 18^{\mathrm{Ink} 4 \mathrm{c}}$ and $\mathrm{p} 27^{\mathrm{Kip} 1}$. However, knockouts of either $\mathrm{p} 18^{\mathrm{Ink} 4 \mathrm{c}}$ or $\mathrm{p} 27^{\mathrm{Kip} 1}$ on a Men $1^{+/-}$background developed different phenotypes. Thus, loss of $\mathrm{p} 18^{\mathrm{Ink} 4 \mathrm{c}}$ accelerated the Men $1^{+/-}$phenotype, with an earlier onset and increased incidence of pituitary, pancreas, parathyroid and thyroid tumours, whereas loss of $\mathrm{p} 27^{\mathrm{Kip} 1}$ had no effect on the
Men $1^{+/-}$phenotype, suggesting that another target of menin may interact differently with $\mathrm{p} 18^{\mathrm{Ink} 4 \mathrm{c}}$ and $\mathrm{p} 27^{\mathrm{Kip} 1}$ (Bai et al. 2007). The MEN-like phenotypes of the CDKI knockout mice have prompted a search for germline mutations in CDKIs in MEN1 patients who did not have mutations in the MEN1 gene. This revealed possible pathogenic heterozygous germline mutations, involving $\mathrm{p} 15^{\mathrm{INK} 4 \mathrm{~A}}, \mathrm{p} 18^{\mathrm{INK} 4 \mathrm{C}}$, $\mathrm{p} 21^{\mathrm{CIP} 1 / \mathrm{WAF} 1}$ and $\mathrm{p} 27^{\mathrm{KIP} 1}$, with frequencies between 0.5 and $1 \cdot 5 \%$, in a small number of patients (Agarwal et al. 2009). Some of these mutations resulted in reduced expression of the CDKI in transfected HEK293 cells, whilst others resulted in decreased binding to their partner CDKs in vitro (Agarwal et al. 2009). Thus, studies of knockout mice have added novel genes and pathways to our understanding of mechanisms of endocrine tumour formation in man. Recently, some potentially oncogenic properties of $\mathrm{p} 27^{\mathrm{KIP} 1}$, which are independent of its CDKI function, have also been described. These oncogenic properties appear to be related to the cytoplasmic functions of $\mathrm{p} 27^{\mathrm{KIP} 1}$, which include regulation of cell motility and the actin cytoskeleton (Lee \& Kim 2009). Novel mouse models will enable further exploration of these putative oncogenic properties of $\mathrm{p} 27^{\mathrm{KIP} 1}$.

\section{Multiple endocrine neoplasia type 4}

Heterozygous germline $\mathrm{p} 27^{\mathrm{KIP} 1}$ mutations have been reported in four MEN1 patients without MEN1 mutations, and this variant has been termed MEN4 (Pellegata et al. 2006, Agarwal et al. 2009). The identification of $\mathrm{p} 27^{\mathrm{KIP} 1}$ as an alternative MEN1 gene resulted from studies of an autosomal recessive trait in a rat model, which showed features of both MEN1 and MEN2, with phaeochromocytoma, thyroid and parathyroid hyperplasia, and pituitary adenoma, and was referred to as MENX (Fritz et al. 2002). The disease locus was mapped to rat chromosome 4 (Piotrowska et al. 2004) and subsequently found to be due to a homozygous frameshift mutation of the $C d k n 1 b$ gene encoding $\mathrm{p} 27^{\mathrm{Kip} 1}$, that resulted in reduced protein levels (Pellegata et al. 2006). A heterozygous germline nonsense mutation in $C D K N 1 B$ was subsequently identified in a patient with MEN1 who did not have a MEN1 mutation (Pellegata et al. 2006). In vitro studies confirmed that the mutant $\mathrm{p} 27^{\mathrm{KIP} 1}$ protein was unstable, and failed to reach the nucleus, where it would normally interact with its target cyclin-CDK complexes (Pellegata et al. 2006). Three other probands with MEN1 tumours but without MEN1 mutations have been reported to have loss-of-function $\mathrm{p} 27^{\mathrm{KIP} 1}$ mutations; however, these are likely to account for $<1 \%$ of probands, and thus appear to be a rare cause of MEN4 in man (Georgitsi et al. 2007, Ozawa et al. 2007, Agarwal et al. 2009, Molatore et al. 2010).

\section{Multiple endocrine neoplasia type 2}

MEN2 is an autosomal dominant disease characterised by the occurrence of medullary thyroid carcinoma (MTC), 
phaeochromocytoma and parathyroid tumours. Three variants referred to as MEN2A, MEN2B and MTC-only occur. In MEN2A, MTC occurs in association with phaeochromocytoma and occasionally parathyroid tumours; in MEN2B, MTC and phaeochromocytoma occur in association with neuromas, ganglioneuromatosis of the gastrointestinal tract, medullated corneal nerve fibres and a Marfanoid habitus (Wohllk et al. 2010); in familial MTC (FMTC)-only, MTC is the sole manifestation. The gene causing the three variants, MEN2A, MEN2B and FMTC is located on chromosome 10q11.2 (Mathew et al. 1987, Simpson et al. 1987, Norum et al. 1990, Lairmore et al. 1991), and encodes the RET proto-oncogene (Donis-Keller et al. 1993, Mulligan et al. 1993, Hofstra et al. 1994). RET is a transmembrane receptor tyrosine kinase which has roles in organogenesis, e.g. of kidneys and neurons (Runeberg-Roos \& Saarma 2007). In the presence of cofactors and ligands, that include members of the glial cell-derived neurotrophic factor family, RET dimerises to trigger autophosphorylation and intracellular signalling (Runeberg-Roos \& Saarma 2007). MEN2-associated RET mutations result in constitutive kinase activity, and thus, mouse models for MEN2 have been generated by use of transgenic and knockin strategies (Tables 1 and 3), as described below.

\section{Models of MEN2A}

The most common MEN2A-associated RET mutation ( $\sim 52 \%$ of MEN2A cases) is the missense mutation Cys634Arg (Eng et al. 1996), and to date, three transgenic models have been generated, which carry this mutation within human RET cDNA, either in multiple tissues or in a tissue-specific manner. All three mouse models developed thyroid C-cell hyperplasia and MTC with high penetrance, and these tumours also expressed calcitonin (Michiels et al. 1997, Kawai et al. 2000, Reynolds et al. 2001). However, adrenal tumours were not found, even in a model that expressed the transgene in the adrenal gland (Michiels et al. 1997). In one of the models, the Cys634Arg-RET transgene was expressed at a high level in the pancreas, and a subset of these mice developed pancreatic cystadenomas and cystadenocarcinomas (Reynolds et al. 2001). Phosphorylated RET dimers were detected in MTCs from transgenic mice, but not in tissues without tumours such as liver and heart, even though the transgene was expressed in those tissues (Michiels et al. 1997, Kawai et al. 2000). Interestingly, in tissues without tumours, there was a high expression of the RET cofactor glycosylphosphatidylinositol-anchored coreceptor GFR $\alpha$, suggesting that this cofactor may interfere with RET dimerisation and thus tumour formation (Kawai et al. 2000). One of the MEN2A transgenic models has been crossed onto four different genetic backgrounds, and the incidence of MTCs on these different backgrounds ranged from 0 to $98 \%$ at 10 months, indicating the presence of strong genetic modifiers in the development of MTC in MEN2A (Cranston \& Ponder 2003).
Another common RET mutation in MEN2A is Cys620Arg ( 7\% of MEN2A cases; Eng et al. 1996), and a knockin model, in which the equivalent mutation was introduced into the mouse Ret gene, has been generated as a model for MEN2A (Table 3). Heterozygous (Ret ${ }^{+/ 620 R}$ ) mice, when old, developed C-cell hyperplasia and adenomas but not MTCs, and a subset of mice developed adrenal gland hyperplasia, but not phaeochromocytomas (Yin et al. 2007). Interestingly, homozygous (Ret $t^{620 \mathrm{R} / 620 \mathrm{R}}$ ) mice developed renal agenesis and intestinal aganglionosis similar to Hirschsprung disease, which is usually caused by heterozygous loss-of-function RET mutations in man (Yin et al. 2007). Further study of this model may help to elucidate the functional characteristics of RET mutations in MEN2A and their effects in both development and tumourigenesis.

\section{Models for MEN2B}

The RET mutations found in 95\% of MEN2B patients is Met918Thr (Eng et al. 1996), and transgenic and knockin models expressing this mutation have been generated (Table 3). The transgene, which was under the control of the $\beta$-hydroxylase promoter, was expressed in the developing sympathetic and enteric nervous systems, and the adrenal medulla, and the transgenic mice developed neuroglial tumours, resembling ganglioneuromas in man, in the sympathetic nervous system and adrenal glands, but not the enteric nervous system (Sweetser et al. 1999). Studies of a knockin model, which harbours the Met918Thr mutation within the mouse Ret gene, have revealed that heterozygous $\left(\right.$ Ret $\left.^{+/ \mathrm{MEN} 2 \mathrm{~B}}\right)$ and homozygous (Ret $\left.{ }^{\mathrm{MEN} 2 \mathrm{~B} / \mathrm{MEN} 2 \mathrm{~B}}\right)$ mice develop C-cell hyperplasia, with an earlier onset and higher penetrance in $\operatorname{Ret}^{\mathrm{MEN} 2 \mathrm{~B} / \mathrm{MEN} 2 \mathrm{~B}}$ mutant mice; however, the C-cell hyperplasia did not progress to thyroid carcinoma in mice aged 10-12 months. Heterozygous Ret $^{+/ \mathrm{MEN} 2 \mathrm{~B}}$ mice also had chromaffin cell hyperplasia, which rarely progressed to phaeochromocytoma, in contrast to the homozygous Ret ${ }^{\text {MEN2B/MEN2B }}$ mice, which all developed phaeochromocytomas by 6 months of age, thereby demonstrating a dosage effect of the MEN2B Ret mutation which has not previously been described in man (Smith-Hicks et al. 2000). Interestingly, the homozygous $R e t^{\mathrm{MEN} 2 \mathrm{~B} / \mathrm{MEN} 2 \mathrm{~B}}$ mice, unlike the homozygous MEN2A mice, did not develop renal agenesis.

\section{HPT-JT syndrome}

HPT-JT syndrome is an autosomal dominant disorder characterised by the occurrence of parathyroid tumours and ossifying fibromas of the mandible and maxilla. Some patients may also develop renal abnormalities and uterine tumours (Newey et al. 2009). The HPT-JT gene, designated HRPT2, is located on chromosome 1q31.2, and demonstration of $\mathrm{LOH}$ in tumours has indicated that it is a likely tumour 
suppressor (Szabo et al. 1995, Teh et al. 1996, 1998, Haven et al. 2000, Hobbs et al. 2002). The HRPT2 gene encodes a 531 amino acid protein, designated parafibromin, that has similarities to yeast Cdc73p, which forms part of the polymerase-associated factor 1 (Paf1) complex (Carpten et al. 2002). Human parafibromin has been shown to also form part of the Paf1 complex, which associates with RNA polymerase II, and functions in: H3K4 methylation via interaction with methyltransferase complexes (RozenblattRosen et al. 2005); chromatin remodelling and initiation of transcription (Newey et al. 2009). Heterozygous HRPT2 mutations have been identified in HPT-JT patients and some patients with familial isolated hyperparathyroidism, and HPT-JT-associated parathyroid tumours have been reported to have allelic deletions or point mutations of HRPT2 (Newey et al. 2010). Furthermore, some HPT-JT-causing missense and nonsense mutant parafibromin proteins lead to a loss of interactions with the Paf1 and methyltransferase complexes (Rozenblatt-Rosen et al. 2005). These findings indicated that the HPT-JT mutations are associated with a loss-of-function, and conventional and inducible knockout mouse models have been generated, using gene trap and Flp/LoxP technologies respectively (Table 3). Conventional homozygous knockout (Hrpt $2^{-/-}$) mice are embryonic lethal by E6.5, and this is likely due to uncontrolled apoptosis at the hatching or implantation stages (Wang et al. 2008). To overcome this embryonic lethality, an inducible model was generated, in which Hrpt 2 could be knocked out at defined time points. Loss of parafibromin during embryogenesis after E6.5 resulted in decreased growth and developmental abnormalities of the central nervous system, with a lack of cellular proliferation, and increased apoptosis, and loss of parafibromin in adult mice led to death within 20 days, with decreases in the sizes of multiple organs due to widespread apoptosis, that was associated with weight loss and a rapid onset of cachexia (Wang et al. 2008). In vitro studies using null MEFs also revealed a decrease in proliferation and an increase in apoptosis, that was associated with down-regulation of several genes involved in cell growth and energy metabolism, which included members of the insulin-like growth factor (Igf) and high-mobility group AT-hook (Hmga) families. Furthermore, parafibromin was shown to bind directly, by chromatin immunoprecipitation assays, to the promoter regions of several of these genes (Wang et al. 2008). In preliminary studies, Hrpt $2^{+-}$knockout mice have been reported to develop parathyroid tumours (Walls et al. 2009).

\section{Disorders of the CaSR}

The CaSR, which is a 1078 amino acid G-protein coupled receptor with seven transmembrane domains and a large 612 amino acid extracellular domain, is predominantly expressed in the parathyroids and kidneys, and is pivotal in extracellular calcium homoeostasis by mediating alterations in the release of PTH from the parathyroids in response to changes in extracellular calcium concentrations (Thakker 2004, Egbuna \& Brown 2008). CaSR mutations resulting in loss-of-function are associated with two hypercalcaemic disorders, which are familial benign hypercalcaemia, also referred to as familial hypocalciuric hypercalcaemia (FHH) and neonatal severe primary hyperparathyroidism (NSHPT; Pollak et al. 1993); whilst gain-of-function CaSR mutations result in two hypocalcaemic disorders, which are autosomal dominant hypocalcaemia with hypercalciuria (ADHH; Pollak et al. 1994, Pearce et al. 1996), and a form of the Bartter syndrome (Vargas-Poussou et al. 2002, Watanabe et al. 2002).

\section{Models for FHH and NSHPT due to loss-of-function CaSR mutations}

$\mathrm{FHH}$ is an autosomal dominant disorder caused by heterozygous loss-of-function CaSR mutations, and NSHPT, which is a life-threatening disorder characterised by severe neonatal hypercalcaemia, undermineralisation of bones and multiple fractures, may be caused by homozygous or de novo heterozygous loss-of-function CaSR mutations (Thakker 2004, Egbuna \& Brown 2008). The loss-offunction CaSR mutations consist of nonsense mutations, frameshifting insertions and deletions and missense mutations that result in an alteration of the CaSR such that the extracellular calcium concentration at which the CaSR produces a half-maximal response $\left(\mathrm{EC}_{50}\right)$ is significantly raised. To provide models for FHH and NSHPT, CaSR knockout mice were therefore generated (Ho et al. 1995; Table 4). Casr heterozygous knockout $\left(\mathrm{Casr}^{+/-}\right)$mice had modest hypercalcaemia with relative hypocalciuria and inappropriately elevated serum PTH, consistent with the features observed in FHH patients (Ho et al. 1995; Table 4). $\mathrm{Casr}^{-1-}$ homozygote knockout mice had early onset of severe hypercalcaemia in association with increased serum PTH concentrations, parathyroid hyperplasia and bone demineralisation. Moreover, $\mathrm{Casr}^{-1-}$ mice died between 3 and 30 days after birth (Ho et al. 1995, Garner et al. 2001). These findings in the Casr ${ }^{-1-}$ mice are representative of the features found in patients with NSHPT (Egbuna \& Brown 2008).

Further insights into the physiological role of the CaSR in extracellular calcium homoeostasis have been gained by breeding Casr knockout mice with Pth and glial cell missing homologue 2 (Gcm2) knockout mice. Thus, Casr ${ }^{-1-}$ Pth $^{-1-}$ mice did not have increased neonatal lethality or skeletal abnormalities (Kos et al. 2003). Furthermore, the overall mean values for serum $\mathrm{Ca}^{2+}$ concentrations and urinary $\mathrm{Ca}^{2+}$ excretion were similar in $\mathrm{Casr}^{-/-} \mathrm{Pth}^{-/-}$mice and wild-type control mice; however, the fine control of calcium homoeostasis was lost in the Casr ${ }^{-/-} \mathrm{Pth}^{-1-}$ mice, which had a much larger range of serum $\mathrm{Ca}^{2+}$ concentrations. These findings demonstrate that the CaSR has PTHindependent roles in calcium homoeostasis (Kos et al. 2003). Furthermore, hypercalcaemic challenge, induced by 
increased oral calcium intake, PTH infusion or dietary phosphate deficiency, resulted in a greater elevation of serum $\mathrm{Ca}^{2+}$ in the $\mathrm{Casr}^{-1-} \mathrm{Pth}^{-/-}$mice, which were found to have a reduced renal calcium clearance and a failure to increase serum calcitonin, compared with $\mathrm{Casr}^{+/+} \mathrm{Pth}^{-1-}$ and $\mathrm{Casr}^{+/-} \mathrm{Pth}^{-\prime-}$ mice (Kantham et al. 2009). However, infusion of PTH in $\mathrm{Casr}^{-1-} \mathrm{Pth}^{-1-}$ mice further reduced the renal calcium clearance, thereby demonstrating that PTH can increase the CaSR-independent $\mathrm{Ca}^{2+}$ reabsorption by the kidney. Thus, it appears that PTH is necessary for the maintenance of normal serum calcium concentrations when facing a hypocalcaemic challenge, but that PTH-independent mechanisms, such as CaSR-stimulated CT secretion and increased renal $\mathrm{Ca}^{2+}$ excretion, are involved in maintaining normal serum calcium concentrations in response to hypercalcaemic challenges (Kantham et al. 2009).

$\mathrm{Casr}^{-/} \mathrm{Gcm} 2^{-/-}$mice, which lack parathyroid glands, also do not have increased neonatal lethality, skeletal abnormalities or hypercalcaemia, which are observed in $\mathrm{Casr}^{-1-} \mathrm{Gcm} 2^{+/+}$mice (Tu et al. 2003). Interestingly, $\mathrm{Casr}^{-/-} \mathrm{Gcm} 2^{-/-}$mice did not appear to demonstrate the large variability in serum $\mathrm{Ca}^{2+}$ levels that was observed in $\mathrm{Casr}^{-1-} \mathrm{Pth}^{-1-}$ mice, and this may be due to the residual PTH production by the thymus.

The absence of bone abnormalities in $\mathrm{Casr}^{-1-} \mathrm{Gcm} 2^{-1-}$ and $\mathrm{Casr}^{-1-} \mathrm{Pth}^{-1-}$ mice, which respectively, ablate the parathyroid glands or abolish PTH, suggested that the bone abnormalities in the $\mathrm{Casr}^{-1-} \mathrm{Gcm} 2^{+/+}$and $\mathrm{Casr}^{-1-}$ $P t h^{+/+}$mice and in NSHPT patients are largely due to hyperparathyroidism ( $\mathrm{Tu}$ et al. 2003). However, the expression of CaSR in bone and cartilage also suggests a role for the CaSR in the skeleton and in contributing to the bone abnormalities observed in the $\mathrm{Casr}^{-1-} \mathrm{Gcm}^{+1+}$ and $\mathrm{Casr}^{-1-} \mathrm{Pth}^{+/+}$mice. An additional complication is the presence of an alternative CaSR splice variant in the Casr knockout mice, which were generated by insertion of the $\mathrm{Neo}^{\mathrm{R}}$ cassette into exon 5 so as to disrupt the gene. However, this results in an incomplete knockout of the receptor because of alternate splicing of the CaSR. The alternative spliced CaSR lacks exon 5, which encodes 77 amino acid residues of the extracellular domain. This spliced receptor lacking exon $5\left({ }^{\operatorname{Exon} 5(-)}\right.$ Casr) is shorter, but retains the majority of the extracellular domain, all of the seven transmembrane domains and the cytoplasmic domain, and is able to compensate for the absence of full-length CaSRs in bone and cartilage (Rodriguez et al. 2005). Thus, the Exon5(-) Casr knockout is incomplete (Rodriguez et al. 2005), and to explore further the skeletal role of the CaSR, tissue-specific knockouts of the CaSR which lacked exon 7, that encodes the 501 amino acids, which form the seven transmembrane domains and four intracellular loops, were generated in the parathyroid, bone and cartilage (Table 4). Parathyroid-specific homozygous knockout (PT-KO) mice died $\sim 2$ weeks after birth and were much smaller than wild types. The PT-KO mice had severe marked hypercalcaemia with elevated serum PTH concentrations, and increased urinary $\mathrm{Ca}^{2+}$ excretion, which is different to the conventional $\mathrm{Casr}^{-1-}$ mice, due to the presence of functional CaSR in the kidney (Chang et al. 2008). PT-KO mice also had severe undermineralisation of the skeleton, consistent with NSHPT. Heterozygous (PT-Het) mice had mild hyperparathyroidism (Chang et al. 2008). Knockout of the CaSR in osteoblasts by utilising a Collagen I-Cre to generate heterozygous (COL-Het) and homozygous (COL-KO) knockout mice, revealed COL-KO mice to have a similar skeletal phenotype to the PT-KO mice, with multiple fractures and profound undermineralisation, due to a lack of differentiation and increased apoptosis, of osteoblasts (Chang et al. 2008). Homozygous knockout of the CaSR in growth plate cells caused embryonic lethality at $\sim$ E12-E13, and to overcome this, an inducible growth platespecific knockout was generated via the use of an ER-Cre. The CaSR was knocked out in growth plates before birth, and this again resulted in bone defects such as short bones, as well as a decrease in mature and terminally differentiated chondrocytes (Chang et al. 2008). Thus, these tissue-specific knockout models demonstrate a role for the CaSR in bone and calcium homoeostasis, and indicate that the skeletal abnormalities seen in patients with NSHPT may not be solely due to hyperparathyroidism.

\section{Models for ADHH due to gain-of-function CaSR mutations}

Gain-of-function CaSR mutations are associated with the disorder of ADHH. The hypocalcaemia is usually mild and asymptomatic, but may sometimes be associated with tetany and seizures. Hyperphosphataemia and hypomagnesaemia are also notable features, and the circulating $\mathrm{PTH}$ concentrations are usually in the low-normal range (Pearce et al. 1996). The CaSR mutations resulting in ADHH are invariably heterozygous missense mutations that result in a lower $\mathrm{EC}_{50}$. To generate a mouse model for $\mathrm{ADHH}$ and such an activating CaSR mutation, two possible strategies could be utilised, which are a knockin approach or searching for a chemically induced mutation (Table 2 and Figs 1 and 3). Indeed, a search of mice derived from use of the chemical iPMS to produce mutants, identified a mouse model for ADHH (Table 4). This mouse model, which was first noted to have opaque flecks of the lens and designated nuclear flecks (Nuf; Hough et al. 2004), has hypocalcaemia and hyperphosphataemia in association with inappropriately low plasma PTH concentrations. In addition, mutant mice may also have widespread ectopic calcification and suffer from sudden death (Hough et al. 2004). These phenotypic features in the mutant Nuf mice are due to a CaSR missense mutation, Leu723Gln, which results in a reduced $\mathrm{EC}_{50}$, consistent with an activating CaSR mutation (Hough et al. 2004). Thus, the Nuf mouse is a model for ADHH due to an activating mutation of the CaSR, and this model may be an important tool to understand the mechanisms of ectopic calcification. 


\section{Inherited hypoparathyroidism}

Hypoparathyroidism, which causes hypocalcaemia and hyperphosphataemia, and is associated with tetany and seizures, can occur as an idiopathic endocrinopathy or as part of a syndrome such as the DiGeorge syndrome (DGS), or the hypoparathyroidism, deafness and renal dysplasia (HDR) syndrome. Forms of familial isolated hypoparathyroidism (FIH) with autosomal dominant, autosomal recessive and $\mathrm{X}$-linked recessive modes of inheritance have been described.

\section{Model for the DGS due to T-box 1 mutations}

DGS is characterised by the occurrence of hypoparathyroidism, immunodeficiency, congenital heart defects and deformities of the ear, nose and mouth. The disorder arises from a congenital failure in the development of the derivatives of the third and fourth pharyngeal pouches, with resulting absence or hypoplasia of the parathyroids and thymus. DGS was reported to be associated with unbalanced translocations and deletions involving chromosome 22q11.2, and further studies identified mutations of the transcription factor, T-box 1 (TBX1), in patients with DGS (Gong et al. 1996, Yagi et al. 2003). Mice that are deleted for $T b \times 1$ have developmental abnormalities of the pharyngeal arches (Table 3). Thus, $T b \times 1^{+/-}$mice have cardiac outflow tract abnormalities, which are defects of the fourth branchial pouch (Jerome \& Papaioannou 2001, Lindsay et al. 2001, Vitelli et al. 2002). However, $T b \times 1^{-/-}$mice have all the developmental anomalies of DGS due to third and fourth branchial defects which include: thymic and parathyroid hypoplasia; abnormal facial structures and cleft palate; skeletal defects and cardiac outflow tract abnormalities (Jerome \& Papaioannou 2001, Lindsay et al. 2001, Vitelli et al. 2002). The basis of the phenotypic differences between DGS patients, who are heterozygous and the $T b \times 1^{+/-}$mice remain to be elucidated. It is plausible that TBX1 dosage, together with downstream genes that are regulated by TBX1 could provide an explanation, but the roles of these putative genes in DGS remain to be elucidated. Several tissue-specific knockout models of Tbx1 have also been generated (Table 3). Knockout of $T b \times 1$ in the pharyngeal endoderm led to neonatal death with malformations identical to $T b \times 1^{-1-}$ mice, and likely due to failure of pharyngeal pouch outgrowth (Arnold et al. 2006b). Inactivation of $T b x 1$ in the otic vesicle led to an absence of the inner ear (Arnold et al. 2006a). Mesodermspecific knockout of $T b \times 1$ led to multiple phenotypes that included malformation of the inner ear, defective pharyngeal patterning, cardiovascular defects, defective development of the proximal mandible and thyroid hypoplasia (Zhang et al. 2006, Braunstein et al. 2009, Lania et al. 2009, Aggarwal et al. 2010). An 'allelic series' of Tbx1 expression showed tissuespecific dosage effects, demonstrating that cardiac outflow tract development is more susceptible to loss of $T b \times 1$ than craniofacial development (Hu et al. 2004). These models have helped to elucidate the roles of TBX1 in organogenesis and DGS, and some of the transcriptional cascades required for development of these structures.

\section{Model for the HDR syndrome due to GATA3 haploinsufficiency}

HDR is an autosomal dominant disorder, characterised by hypocalcaemia with undetectable or inappropriately normal serum concentrations of PTH; bilateral sensorineural deafness and variable renal abnormalities, including cysts, hypoplasia and aplasia (Bilous et al. 1992, Muroya et al. 2001, Nesbit et al. 2004, Ali et al. 2007). HDR is due to GATA3 haploinsufficiency (Van Esch et al. 2000), and studies of Gata3 knockout mice have revealed that these develop features of HDR (Table 3). Heterozygous $\left(\mathrm{Gata}^{+/-}\right)$mice initially appeared phenotypically normal (Pandolfi et al. 1995); however, further studies have shown that Gata3 ${ }^{+/-}$mice develop two of the three components of the HDR syndrome. When challenged with a low-calcium diet, Gata $3^{+/-}$mice were unable to mount the appropriate parathyroid response, and thus had a lower plasma PTH and calcium than their wild-type littermates, as well as smaller parathyroid glands with lower proliferation rates (Grigorieva et al. 2010). Gata $3^{+/-}$mice had smaller parathyroid-thymus primordia at E11.5, with fewer cells expressing $\mathrm{Gcm} 2$, and Gata $3^{-/-}$mice had no primordia after E12.5, with a complete absence of Gcm2expressing cells, indicating a defect of parathyroid gland development in both Gata $^{+/-}$and Gata3 ${ }^{-/-}$mice (Grigorieva et al. 2010). Indeed, GATA3 bound to a functional double GATA motif in the GCMB promoter in human parathyroid adenoma cells, demonstrating a direct link between GATA3 and GCMB as part of a critical transcriptional cascade in parathyroid development (Grigorieva et al. 2010). Gata $3^{+/-}$mice had hearing loss starting in the early postnatal period, and progressing through adulthood (van der Wees et al. 2004). This hearing loss was found to be due to cochlear abnormalities starting with outer hair cell dysfunction at the apical cochlea, and progressing to the base of the cochlea (van der Wees et al. 2004, van Looij et al. 2005). Gata3 null $\left(\right.$ Gata $\left.^{-/-}\right)$mice are embryonically lethal and died at E11-E12 with internal bleeding, growth retardation, severe deformities of the brain and spinal cord, defective haematopoiesis, lack of T-cell differentiation and a lack of noradrenaline in the sympathetic nervous system (Pandolfi et al. 1995, Lim et al. 2000). The lack of noradrenaline, due to an absence of tyrosine hydroxylase and dopamine $\beta$-hydroxylase enzymes, was overcome by feeding catecholamine intermediates to pregnant dams, thereby partially rescuing the Gata $^{-1-}$ embryos to E12.5-E16.5 (Lim et al. 2000). This revealed other phenotypic abnormalities, including thymic hypoplasia, renal hypoplasia and defects in structures derived from cephalic neural crest cells (Lim et al. 2000, Grote et al. 2006). Rescue of Gata $3^{-/-}$embryos to E18.5 by administration of adrenergic receptor agonists also revealed cardiac defects including ventricular and aortic arch defects 
Table 5 Some online resources and databases that provide details for generating mouse models

\section{Contents}

\author{
Resource \\ Mouse Genome Informatics \\ (MGI), The Jackson \\ Laboratory
}

International Mouse Strain Resource (IMSR), The Jackson Laboratory

International Knockout Mouse Consortium

Mouse Phenome Database, The Jackson Laboratory
Data from genome, expression, tumour biology and ontology databases, disease models searchable by gene, phenotype and system. Includes International Mouse Mutagenesis Consortium (IMMC), International Complex Traits Consortium (CTC) and International Gene Trap Consortium (IGCT)

Database of mouse strains and stocks, including inbred, mutant and genetically modified mice

Database of available knockout ES cell lines; includes Knockout Mouse Project (KOMP), European Conditional Mouse Mutagenesis Programme (EUCOMM), North American Conditional Mouse Mutagenesis Project (NorCOMM) and Texas A\&M Institute for Genomic Medicine (TIGM)

Baseline phenotypic data from different inbred mouse strains
URL

http://www.informatics.jax.org/

http://www.findmice.org/

http://www.knockoutmouse.org/ or https://www.komp.org/ikmc/

http://phenome.jax.org/
(Raid et al. 2009). These studies reveal the role of GATA3 and catecholamines in organogenesis and in the HDR syndrome.

\section{Models for FIH due to PTH and GCMB mutations}

Both autosomal dominant and autosomal recessive forms of FIH have been found to be due to mutations in PTH and GCMB, which is a member of a small family of GCM transcription factors whose expression appears to be restricted to the developing and adult parathyroid glands (Kim et al. 1998). FIH-associated PTH and GCMB mutations likely lead to a loss-of-function, and knockout mice for Pth and the mouse GCMB homologue Gcm2, develop hypoparathyroidism (Table 3). Pth $h^{+/-}$mice were viable with no apparent phenotypic abnormalities. However, PTH null $\left(\mathrm{Pth}^{-/-}\right)$ mice had enlarged parathyroid glands with an absence of PTH expression, but with substantial CaSR expression. Pth ${ }^{-1-}$ mice also had abnormal skull formation with enhanced mineralisation, along with shortening of the long bones and other bone abnormalities (Miao et al. 2002). When maintained on a normal calcium diet, $\mathrm{Pth}^{-I^{-}}$mice developed hypocalcaemia and hyperphosphataemia, consistent with hypoparathyroidism, that was associated with an increased serum $1,25(\mathrm{OH})_{2} \mathrm{D}_{3}$ concentration. Moreover, when given a low-calcium diet, serum $1,25(\mathrm{OH})_{2} \mathrm{D}_{3}$ concentrations further increased in the $\mathrm{Pth}^{-/}$mice, and this led to increased bone resorption and a maintenance of serum calcium at the expense of osteopenia (Miao et al. 2004).

Mice lacking a copy of $\mathrm{Gcm} 2\left(\mathrm{Gcm} 2^{+/-}\right)$appear normal, viable and fertile. However, Gcm $2^{-1-}$ mice have an absence of parathyroid glands, with hypocalcaemia and hyperphosphataemia, consistent with hypoparathyroidism. However, in contrast to $\mathrm{Pth}^{-/-}$mice, PTH was detected in the serum and this PTH was produced by a cluster of cells in the thymus (Gunther et al. 2000). A detailed analysis of Gcm $2^{-/-}$ embryos showed that a parathyroid domain was initially formed, with transient expression of CaSR, before being lost by E12.5 due to apoptotic cell death. GCM2 and GATA3 form part of a transcriptional cascade that facilitates parathyroid development (Liu et al. 2007, Grigorieva et al. 2010).

\section{Conclusions}

Mouse models for inherited endocrine and metabolic syndromes have been generated by a variety of strategies, and have provided new and valuable insights into the pathogenesis of these complex disorders. These studies have been used both to generate models for disorders with known genetic causes, and to identify novel genes causing mouse phenotypes similar to those in man, thus increasing our understanding of the molecular and genetic mechanisms and pathways in these disorders. Furthermore, the resources have been developed to facilitate the generation of mouse models for human diseases (Table 5), and this will help to increase our understanding of the molecular and systemic mechanisms underlying human disorders, as well as providing pre-clinical models for assessing therapies.

\section{Declaration of interest}

The authors declare that there is no conflict of interest that could be perceived as prejudicing the impartiality of the research reported.

\section{Funding}

S E P and R V T are grateful to the Medical Research Council UK (grants G9825289 and G1000467) for support. 


\section{References}

Acevedo-Arozena A, Wells S, Potter P, Kelly M, Cox RD \& Brown SD 2008 ENU mutagenesis, a way forward to understand gene function. Annual Review of Genomics and Human Genetics 9 49-69. (doi:10.1146/annurev. genom.9.081307.164224)

Agarwal SK, Mateo CM \& Marx SJ 2009 Rare germline mutations in cyclindependent kinase inhibitor genes in multiple endocrine neoplasia type 1 and related states. Journal of Clinical Endocrinology and Metabolism 94 1826-1834. (doi:10.1210/jc.2008-2083)

Aggarwal VS, Carpenter C, Freyer L, Liao J, Petti M \& Morrow BE 2010 Mesodermal Tbx1 is required for patterning the proximal mandible in mice. Developmental Biology 344 669-681. (doi:10.1016/j.ydbio.2010.05. 496)

Ali A, Christie PT, Grigorieva IV, Harding B, Van Esch H, Ahmed SF, Bitner-Glindzicz M, Blind E, Bloch C, Christin P et al. 2007 Functional characterization of GATA3 mutations causing the hypoparathyroidismdeafness-renal (HDR) dysplasia syndrome: insight into mechanisms of DNA binding by the GATA3 transcription factor. Human Molecular Genetics 16 265-275. (doi:10.1093/hmg/ddl454)

Arnold JS, Braunstein EM, Ohyama T, Groves AK, Adams JC, Brown MC \& Morrow BE 2006a Tissue-specific roles of Tbx1 in the development of the outer, middle and inner ear, defective in 22q11DS patients. Human Molecular Genetics 15 1629-1639. (doi:10.1093/hmg/ddl084)

Arnold JS, Werling U, Braunstein EM, Liao J, Nowotschin S, Edelmann W, Hebert JM \& Morrow BE 2006b Inactivation of Tbx1 in the pharyngeal endoderm results in 22q11DS malformations. Development 133 977-987. (doi:10.1242/dev.02264)

Bai F, Pei XH, Nishikawa T, Smith MD \& Xiong Y 2007 p18Ink4c, but not p27Kip1, collaborates with Men1 to suppress neuroendocrine organ tumors. Molecular and Cellular Biology 27 1495-1504. (doi:10.1128/MCB. 01764-06)

Barbaric I, Wells S, Russ A \& Dear TN 2007 Spectrum of ENU-induced mutations in phenotype-driven and gene-driven screens in the mouse. Environmental and Molecular Mutagenesis 48 124-142. (doi:10.1002/em. 20286)

Bassett JH, Rashbass P, Harding B, Forbes SA, Pannett AA \& Thakker RV 1999 Studies of the murine homolog of the multiple endocrine neoplasia type 1 (MEN1) gene, men1. Journal of Bone and Mineral Research 14 3-10. (doi:10.1359/jbmr.1999.14.1.3)

Beck L, Soumounou Y, Martel J, Krishnamurthy G, Gauthier C, Goodyer CG \& Tenenhouse HS 1997 Pex/PEX tissue distribution and evidence for a deletion in the $3^{\prime}$ region of the Pex gene in X-linked hypophosphatemic mice. The Journal of Clinical Investigation 99 1200-1209.

Bertolino P, Radovanovic I, Casse H, Aguzzi A, Wang ZQ \& Zhang CX $2003 a$ Genetic ablation of the tumor suppressor menin causes lethality at mid-gestation with defects in multiple organs. Mechanisms of Development 120 549-560. (doi:10.1016/S0925-4773(03)00039-X)

Bertolino P, Tong WM, Galendo D, Wang ZQ \& Zhang CX 2003b Heterozygous Men1 mutant mice develop a range of endocrine tumors mimicking multiple endocrine neoplasia type 1. Molecular Endocrinology 17 1880-1892. (doi:10.1210/me.2003-0154)

Bertolino P, Tong WM, Herrera PL, Casse H, Zhang CX \& Wang ZQ 2003c Pancreatic beta-cell-specific ablation of the multiple endocrine neoplasia type 1 (MEN1) gene causes full penetrance of insulinoma development in mice. Cancer Research 63 4836-4841.

Bilous RW, Murty G, Parkinson DB, Thakker RV, Coulthard MG, Burn J, Mathias D \& Kendall-Taylor P 1992 Brief report: autosomal dominant familial hypoparathyroidism, sensorineural deafness, and renal dysplasia. New England Journal of Medicine 327 1069-1074. (doi:10.1056/ NEJM199210083271506)

Biondi CA, Gartside MG, Waring P, Loffler KA, Stark MS, Magnuson MA, Kay GF \& Hayward NK 2004 Conditional inactivation of the MEN1 gene leads to pancreatic and pituitary tumorigenesis but does not affect normal development of these tissues. Molecular and Cellular Biology 24 3125-3131. (doi:10.1128/MCB.24.8.3125-3131.2004)
Braunstein EM, Monks DC, Aggarwal VS, Arnold JS \& Morrow BE 2009 Tbx1 and Brn4 regulate retinoic acid metabolic genes during cochlear morphogenesis. BMC Developmental Biology 9 31. (doi:10.1186/1471213X-9-31)

Carpten JD, Robbins CM, Villablanca A, Forsberg L, Presciuttini S, Bailey-Wilson J, Simonds WF, Gillanders EM, Kennedy AM, Chen JD et al. 2002 HRPT2, encoding parafibromin, is mutated in hyperparathyroidism-jaw tumor syndrome. Nature Genetics 32 676-680. (doi:10. 1038/ng1048)

Chandrasekharappa SC, Guru SC, Manickam P, Olufemi SE, Collins FS, Emmert-Buck MR, Debelenko LV, Zhuang Z, Lubensky IA, Liotta LA et al. 1997 Positional cloning of the gene for multiple endocrine neoplasiatype 1. Science $\mathbf{2 7 6}$ 404-407. (doi:10.1126/science.276.5311.404)

Chang W, Tu C, Chen TH, Bikle D \& Shoback D 2008 The extracellular calcium-sensing receptor (CaSR) is a critical modulator of skeletal development. Science Signaling 1 ra1. (doi:10.1126/scisignal.1159945)

Coghill EL, Hugill A, Parkinson N, Davison C, Glenister P, Clements S, Hunter J, Cox RD \& Brown SD 2002 A gene-driven approach to the identification of ENU mutants in the mouse. Nature Genetics 30 255-256. (doi:10.1038/ng847)

Collins FS, Finnell RH, Rossant J \& Wurst W 2007a A new partner for the international knockout mouse consortium. Cell 129 235. (doi:10.1016/j. cell.2007.04.007)

Collins FS, Rossant J \& Wurst W 2007b A mouse for all reasons. Cell 128 9-13. (doi:10.1016/j.cell.2006.12.018)

Crabtree JS, Scacheri PC, Ward JM, Garrett-Beal L, Emmert-Buck MR, Edgemon KA, Lorang D, Libutti SK, Chandrasekharappa SC, Marx SJ et al. 2001 A mouse model of multiple endocrine neoplasia, type 1, develops multiple endocrine tumors. PNAS 98 1118-1123. (doi:10.1073/pnas.98.3. 1118)

Crabtree JS, Scacheri PC, Ward JM, McNally SR, Swain GP, Montagna C, Hager JH, Hanahan D, Edlund H, Magnuson MA et al. 2003 Of mice and MEN1: insulinomas in a conditional mouse knockout. Molecular and Cellular Biology 23 6075-6085. (doi:10.1128/MCB.23.17.6075-6085. 2003)

Cranston AN \& Ponder BA 2003 Modulation of medullary thyroid carcinoma penetrance suggests the presence of modifier genes in a RET transgenic mouse model. Cancer Research 63 4777-4780.

Deng C, Zhang P, Harper JW, Elledge SJ \& Leder P 1995 Mice lacking p21CIP1/WAF1 undergo normal development, but are defective in G1 checkpoint control. Cell 82 675-684. (doi:10.1016/0092-8674(95)90039-X)

Donis-Keller H, Dou S, Chi D, Carlson KM, Toshima K, Lairmore TC, Howe JR, Moley JF, Goodfellow P \& Wells SA Jr 1993 Mutations in the RET proto-oncogene are associated with MEN 2A and FMTC. Human Molecular Genetics 2 851-856. (doi:10.1093/hmg/2.7.851)

Egbuna OI \& Brown EM 2008 Hypercalcaemic and hypocalcaemic conditions due to calcium-sensing receptor mutations. Best Practice and Research. Clinical Rheumatology 22 129-148. (doi:10.1016/j.berh.2007. 11.006)

Eng C, Clayton D, Schuffenecker I, Lenoir G, Cote G, Gagel RF, van Amstel HK, Lips CJ, Nishisho I, Takai SI et al. 1996 The relationship between specific RET proto-oncogene mutations and disease phenotype in multiple endocrine neoplasia type 2. International RET mutation consortium analysis. Journal of the American Medical Association 276 1575-1579. (doi:10. 1001/jama.276.19.1575)

Engleka KA, Wu M, Zhang M, Antonucci NB \& Epstein JA 2007 Menin is required in cranial neural crest for palatogenesis and perinatal viability. Developmental Biology 311 524-537. (doi:10.1016/j.ydbio.2007.08.057)

Fisher EM, Lana-Elola E, Watson SD, Vassiliou G \& Tybulewicz VL 2009 New approaches for modelling sporadic genetic disease in the mouse. Disease Models \& Mechanisms 2 446-453. (doi:10.1242/dmm.001644)

Fontaniere S, Tost J, Wierinckx A, Lachuer J, Lu J, Hussein N, Busato F, Gut I, Wang ZQ \& Zhang CX 2006 Gene expression profiling in insulinomas of Men1 beta-cell mutant mice reveals early genetic and epigenetic events involved in pancreatic beta-cell tumorigenesis. Endocrine-Related Cancer 13 1223-1236. (doi:10.1677/erc.1.01294) 
Fontaniere S, Duvillie B, Scharfmann R, Carreira C, Wang ZQ \& Zhang CX 2008 Tumour suppressor menin is essential for development of the pancreatic endocrine cells. Journal of Endocrinology 199 287-298. (doi:10. 1677/JOE-08-0289)

Franklin DS, Godfrey VL, Lee H, Kovalev GI, Schoonhoven R, Chen-Kiang S, Su L \& Xiong Y 1998 CDK inhibitors p18(INK4c) and p27(Kip1) mediate two separate pathways to collaboratively suppress pituitary tumorigenesis. Genes and Development 12 2899-2911. (doi:10.1101/gad.12. 18.2899)

Franklin DS, Godfrey VL, O’Brien DA, Deng C \& Xiong Y 2000 Functional collaboration between different cyclin-dependent kinase inhibitors suppresses tumor growth with distinct tissue specificity. Molecular and Cellular Biology 20 6147-6158. (doi:10.1128/MCB.20.16.6147-6158. 2000)

Friedel RH, Plump A, Lu X, Spilker K, Jolicoeur C, Wong K, Venkatesh TR, Yaron A, Hynes M, Chen B et al. 2005 Gene targeting using a promoterless gene trap vector ("targeted trapping") is an efficient method to mutate a large fraction of genes. PNAS 102 13188-13193. (doi:10.1073/pnas. 0505474102)

Friedman E, Sakaguchi K, Bale AE, Falchetti A, Streeten E, Zimering MB, Weinstein LS, McBride WO, Nakamura Y, Brandi ML et al. 1989 Clonality of parathyroid tumors in familial multiple endocrine neoplasia type 1. New England Journal of Medicine 321 213-218. (doi:10.1056/NEJM198907 273210402)

Fritz A, Walch A, Piotrowska K, Rosemann M, Schaffer E, Weber K, Timper A, Wildner G, Graw J, Hofler $\mathrm{H}$ et al. 2002 Recessive transmission of a multiple endocrine neoplasia syndrome in the rat. Cancer Research 62 3048-3051.

Garner SC, Pi M, Tu Q \& Quarles LD 2001 Rickets in cation-sensing receptor-deficient mice: an unexpected skeletal phenotype. Endocrinology 142 3996-4005. (doi:10.1210/en.142.9.3996)

Georgitsi M, Raitila A, Karhu A, van der Luijt RB, Aalfs CM, Sane T, Vierimaa O, Makinen MJ, Tuppurainen K, Paschke R et al. 2007 Germline CDKN1B/p27Kip1 mutation in multiple endocrine neoplasia. Journal of Clinical Endocrinology and Metabolism 92 3321-3325. (doi:10.1210/ jc.2006-2843)

Gong W, Emanuel BS, Collins J, Kim DH, Wang Z, Chen F, Zhang G, Roe B \& Budarf ML 1996 A transcription map of the DiGeorge and velo-cardiofacial syndrome minimal critical region on 22q11. Human Molecular Genetics 5 789-800. (doi:10.1093/hmg/5.6.789)

Grigorieva IV, Mirczuk S, Gaynor KU, Nesbit MA, Grigorieva EF, Wei Q, Ali A, Fairclough RJ, Stacey JM, Stechman MJ et al. 2010 Gata3-deficient mice develop parathyroid abnormalities due to dysregulation of the parathyroidspecific transcription factor Gcm2. Journal of Clinical Investigation $\mathbf{1 2 0}$ 2144-2155. (doi:10.1172/JCI42021)

Grote D, Souabni A, Busslinger M \& Bouchard M 2006 Pax 2/8-regulated Gata 3 expression is necessary for morphogenesis and guidance of the nephric duct in the developing kidney. Development 133 53-61. (doi:10. 1242/dev.02184)

Gunther T, Chen ZF, Kim J, Priemel M, Rueger JM, Amling M, Moseley JM, Martin TJ, Anderson DJ \& Karsenty G 2000 Genetic ablation of parathyroid glands reveals another source of parathyroid hormone. Nature 406 199-203. (doi:10.1038/35018111)

Guru SC, Goldsmith PK, Burns AL, Marx SJ, Spiegel AM, Collins FS \& Chandrasekharappa SC 1998 Menin, the product of the MEN1 gene, is a nuclear protein. PNAS 95 1630-1634. (doi:10.1073/pnas.95.4.1630)

Hacking DF 2008 'Knock, and it shall be opened': knocking out and knocking in to reveal mechanisms of disease and novel therapies. Early Human Development 84 821-827. (doi:10.1016/j.earlhumdev.2008.09.011)

Hall B, Limaye A \& Kulkarni AB 2009 Overview: generation of gene knockout mice. Current Protocols in Cell Biology Chapter 19 Unit 19.12 $11-17$.

Harding B, Lemos MC, Reed AA, Walls GV, Jeyabalan J, Bowl MR, Tateossian H, Sullivan N, Hough T, Fraser WD et al. 2009 Multiple endocrine neoplasia type 1 knockout mice develop parathyroid, pancreatic, pituitary and adrenal tumours with hypercalcaemia, hypophosphataemia and hypercorticosteronaemia. Endocrine-Related Cancer 16 1313-1327. (doi:10.1677/ERC-09-0082)
Haruyama N, Cho A \& Kulkarni AB 2009 Overview: engineering transgenic constructs and mice. Current Protocols in Cell Biology Chapter 19 Unit 19. 10 .

Haven CJ, Wong FK, van Dam EW, van der Juijt R, van Asperen C, Jansen J, Rosenberg C, de Wit M, Roijers J, Hoppener J et al. 2000 A genotypic and histopathological study of a large Dutch kindred with hyperparathyroidismjaw tumor syndrome. Journal of Clinical Endocrinology and Metabolism $\mathbf{8 5}$ 1449-1454. (doi:10.1210/jc.85.4.1449)

Hickman-Davis JM \& Davis IC 2006 Transgenic mice. Paediatric Respiratory Reviews 7 49-53.

Ho C, Conner DA, Pollak MR, Ladd DJ, Kifor O, Warren HB, Brown EM, Seidman JG \& Seidman CE 1995 A mouse model of human familial hypocalciuric hypercalcemia and neonatal severe hyperparathyroidism. Nature Genetics 11 389-394. (doi:10.1038/ng1295-389)

Hobbs MR, Rosen IB \& Jackson CE 2002 Revised 14.7-cM locus for the hyperparathyroidism-jaw tumor syndrome gene, HRPT2. American Journal of Human Genetics 70 1376-1377. (doi:10.1086/340093)

Hofstra RM, Landsvater RM, Ceccherini I, Stulp RP, Stelwagen T, Luo Y, Pasini B, Hoppener JW, van Amstel HK, Romeo G et al. 1994 A mutation in the RET proto-oncogene associated with multiple endocrine neoplasia type 2B and sporadic medullary thyroid carcinoma. Nature 367 375-376. (doi:10.1038/367375a)

Hough TA, Bogani D, Cheeseman MT, Favor J, Nesbit MA, Thakker RV \& Lyon MF 2004 Activating calcium-sensing receptor mutation in the mouse is associated with cataracts and ectopic calcification. PNAS 101 13566-13571. (doi:10.1073/pnas.0405516101)

Hu T, Yamagishi H, Maeda J, McAnally J, Yamagishi C \& Srivastava D 2004 Tbx1 regulates fibroblast growth factors in the anterior heart field through a reinforcing autoregulatory loop involving forkhead transcription factors. Development 131 5491-5502. (doi:10.1242/dev.01399)

Huang SC, Zhuang Z, Weil RJ, Pack S, Wang C, Krutzsch HC, Pham TA \& Lubensky IA 1999 Nuclear/cytoplasmic localization of the multiple endocrine neoplasia type 1 gene product, menin. Laboratory Investigation 79 301-310.

Jerome LA \& Papaioannou VE 2001 DiGeorge syndrome phenotype in mice mutant for the T-box gene, Tbx1. Nature Genetics 27 286-291. (doi:10. 1038/85845)

Ji Y, Prasad NB, Novotny EA, Kaur S, Elkahloun A, Chen Y, Zhang RZ, Chu ML, Agarwal SK, Marx SJ et al. 2007 Mouse embryo fibroblasts lacking the tumor suppressor menin show altered expression of extracellular matrix protein genes. Molecular Cancer Research 5 1041-1051. (doi:10.1158/15417786.MCR-06-0379)

Kantham L, Quinn SJ, Egbuna OI, Baxi K, Butters R, Pang JL, Pollak MR, Goltzman D \& Brown EM 2009 The calcium-sensing receptor (CaSR) defends against hypercalcemia independently of its regulation of parathyroid hormone secretion. American Journal of Physiology. Endocrinology and Metabolism 297 E915-E923. (doi:10.1152/ajpendo.00315.2009)

Karnik SK, Hughes CM, Gu X, Rozenblatt-Rosen O, McLean GW, Xiong Y, Meyerson M \& Kim SK 2005 Menin regulates pancreatic islet growth by promoting histone methylation and expression of genes encoding p27Kip1 and p18INK4c. PNAS 102 14659-14664. (doi:10.1073/pnas.0503484102)

Kawai K, Iwashita T, Murakami H, Hiraiwa N, Yoshiki A, Kusakabe M, Ono K, Iida K, Nakayama A \& Takahashi M 2000 Tissue-specific carcinogenesis in transgenic mice expressing the RET proto-oncogene with a multiple endocrine neoplasia type 2A mutation. Cancer Research 60 5254-5260.

Kim J, Jones BW, Zock C, Chen Z, Wang H, Goodman CS \& Anderson DJ 1998 Isolation and characterization of mammalian homologs of the Drosophila gene glial cells missing. PNAS 95 12364-12369. (doi:10.1073/ pnas.95.21.12364)

Kiyokawa H, Kineman RD, Manova-Todorova KO, Soares VC, Hoffman ES, Ono M, Khanam D, Hayday AC, Frohman LA \& Koff A 1996 Enhanced growth of mice lacking the cyclin-dependent kinase inhibitor function of p27(Kip1). Cell 85 721-732. (doi:10.1016/S0092-8674(00)81238-6)

Kovacs CS, Ho-Pao CL, Hunzelman JL, Lanske B, Fox J, Seidman JG, Seidman CE \& Kronenberg HM 1998 Regulation of murine fetal-placental calcium metabolism by the calcium-sensing receptor. Journal of Clinical Investigation 101 2812-2820. 
Kos CH, Karaplis AC, Peng JB, Hediger MA, Goltzman D, Mohammad KS, Guise TA \& Pollak MR 2003 The calcium-sensing receptor is required for normal calcium homeostasis independent of parathyroid hormone. Journal of Clinical Investigation 111 1021-1028. (doi:10.1172/JCI200317416)

Kottemann MC \& Bale AE 2009 Characterization of DNA damagedependent cell cycle checkpoints in a menin-deficient model. DNA Repair 8 944-952. (doi:10.1016/j.dnarep.2009.06.001)

Lairmore TC, Howe JR, Korte JA, Dilley WG, Aine L, Aine E, Wells SA Jr \& Donis-Keller H 1991 Familial medullary thyroid carcinoma and multiple endocrine neoplasia type $2 \mathrm{~B}$ map to the same region of chromosome 10 as multiple endocrine neoplasia type 2A. Genomics 9 181-192. (doi:10.1016/ 0888-7543(91)90237-9)

Lania G, Zhang Z, Huynh T, Caprio C, Moon AM, Vitelli F \& Baldini A 2009 Early thyroid development requires a Tbx1-Fgf8 pathway. Developmental Biology 328 109-117. (doi:10.1016/j.ydbio.2009.01.014)

Lapenna S \& Giordano A 2009 Cell cycle kinases as therapeutic targets for cancer. Nature Reviews. Drug Discovery 8 547-566. (doi:10.1038/nrd2907)

Larsson C, Skogseid B, Oberg K, Nakamura Y \& Nordenskjold M 1988 Multiple endocrine neoplasia type 1 gene maps to chromosome 11 and is lost in insulinoma. Nature 332 85-87. (doi:10.1038/332085a0)

Lee J \& Kim SS 2009 The function of p27 KIP1 during tumor development. Experimental \& Molecular Medicine 41 765-771. (doi:10.3858/emm.2009.41. 11.102)

Lemmens I, Van de Ven WJ, Kas K, Zhang CX, Giraud S, Wautot V, Buisson N, De Witte K, Salandre J, Lenoir G et al. 1997 Identification of the multiple endocrine neoplasia type 1 (MEN1) gene. The European Consortium on MEN1. Human Molecular Genetics 6 1177-1183. (doi:10. 1093/hmg/6.7.1177)

Lemos MC \& Thakker RV 2008 Multiple endocrine neoplasia type 1 (MEN1): analysis of 1336 mutations reported in the first decade following identification of the gene. Human Mutation 29 22-32. (doi:10.1002/humu. 20605)

Lemos MC, Harding B, Reed AA, Jeyabalan J, Walls GV, Bowl MR, Sharpe J, Wedden S, Moss JE, Ross A et al. 2009 Genetic background influences embryonic lethality and the occurrence of neural tube defects in Men1 null mice: relevance to genetic modifiers. Journal of Endocrinology 203 133-142. (doi:10.1677/JOE-09-0124)

Libutti SK, Crabtree JS, Lorang D, Burns AL, Mazzanti C, Hewitt SM, O'Connor S, Ward JM, Emmert-Buck MR, Remaley A et al. 2003 Parathyroid gland-specific deletion of the mouse Men1 gene results in parathyroid neoplasia and hypercalcemic hyperparathyroidism. Cancer Research 63 8022-8028.

Lim KC, Lakshmanan G, Crawford SE, Gu Y, Grosveld F \& Engel JD 2000 Gata3 loss leads to embryonic lethality due to noradrenaline deficiency of the sympathetic nervous system. Nature Genetics 25 209-212. (doi:10.1038/ 76080)

Lindsay EA, Vitelli F, Su H, Morishima M, Huynh T, Pramparo T, Jurecic V, Ogunrinu G, Sutherland HF, Scambler PJ et al. 2001 Tbx1 haploinsufficieny in the DiGeorge syndrome region causes aortic arch defects in mice. Nature 410 97-101. (doi:10.1038/35065105)

Liu Z, Yu S \& Manley NR 2007 Gcm2 is required for the differentiation and survival of parathyroid precursor cells in the parathyroid/thymus primordia. Developmental Biology 305 333-346. (doi:10.1016/j.ydbio.2007.02.014)

Loffler KA, Biondi CA, Gartside M, Waring P, Stark M, Serewko-Auret MM, Muller HK, Hayward NK \& Kay GF 2007 Broad tumor spectrum in a mouse model of multiple endocrine neoplasia type 1. International Journal of Cancer 120 259-267. (doi:10.1002/ijc.22288)

Lorenz B, Francis F, Gempel K, Boddrich A, Josten M, Schmahl W, Schmidt J, Lehrach H, Meitinger T \& Strom TM 1998 Spermine deficiency in Gy mice caused by deletion of the spermine synthase gene. Human Molecular Genetics 7 541-547.

van Looij MA, van der Burg H, van der Giessen RS, de Ruiter MM, van der Wees J, van Doorninck JH, De Zeeuw CI \& van Zanten GA 2005 GATA3 haploinsufficiency causes a rapid deterioration of distortion product otoacoustic emissions (DPOAEs) in mice. Neurobiology of Disease 20 890-897. (doi:10.1016/j.nbd.2005.05.025)
Lu J, Herrera PL, Carreira C, Bonnavion R, Seigne C, Calender A, Bertolino P \& Zhang CX 2010 Alpha cell-specific Men1 ablation triggers the transdifferentiation of glucagon-expressing cells and insulinoma development. Gastroenterology 138 1954-1965. (doi:10.1053/j.gastro.2010.01.046)

Martin-Caballero J, Flores JM, Garcia-Palencia P \& Serrano M 2001 Tumor susceptibility of p21(Waf1/Cip1)-deficient mice. Cancer Research 61 6234-6238.

Mathew CG, Chin KS, Easton DF, Thorpe K, Carter C, Liou GI, Fong SL, Bridges CD, Haak H, Kruseman AC et al. 1987 A linked genetic marker for multiple endocrine neoplasia type 2A on chromosome 10. Nature 328 527-528. (doi:10.1038/328527a0)

Meyer RA Jr, Henley CM, Meyer MH, Morgan PL, McDonald AG, Mills C \& Price DK 1998 Partial deletion of both the spermine synthase gene and the Pex gene in the X-linked hypophosphatemic, gyro (Gy) mouse. Genomics 48 289-295.

Miao D, He B, Karaplis AC \& Goltzman D 2002 Parathyroid hormone is essential for normal fetal bone formation. Journal of Clinical Investigation 109 1173-1182. (doi:10.1172/JCI14817)

Miao D, He B, Lanske B, Bai XY, Tong XK, Hendy GN, Goltzman D \& Karaplis AC 2004 Skeletal abnormalities in Pth-null mice are influenced by dietary calcium. Endocrinology 145 2046-2053. (doi:10.1210/en. 2003-1097)

Michiels FM, Chappuis S, Caillou B, Pasini A, Talbot M, Monier R, Lenoir GM, Feunteun J \& Billaud M 1997 Development of medullary thyroid carcinoma in transgenic mice expressing the RET protooncogene altered by a multiple endocrine neoplasia type 2A mutation. PNAS 94 3330-3335. (doi:10.1073/pnas.94.7.3330)

Milne TA, Hughes CM, Lloyd R, Yang Z, Rozenblatt-Rosen O, Dou Y, Schnepp RW, Krankel C, Livolsi VA, Gibbs D et al. 2005 Menin and MLL cooperatively regulate expression of cyclin-dependent kinase inhibitors. PNAS 102 749-754. (doi:10.1073/pnas.0408836102)

Molatore S, Marinoni I, Lee M, Pulz E, Ambrosio MR, degli Uberti EC, Zatelli MC \& Pellegata NS 2010 A novel germline CDKN1B mutation causing multiple endocrine tumors: clinical, genetic and functional characterization. Human Mutation 31 E1825-E1835. (doi:10.1002/humu. 21354)

Mulligan LM, Kwok JB, Healey CS, Elsdon MJ, Eng C, Gardner E, Love DR, Mole SE, Moore JK, Papi L et al. 1993 Germ-line mutations of the RET proto-oncogene in multiple endocrine neoplasia type 2A. Nature 363 458-460. (doi:10.1038/363458a0)

Muroya K, Hasegawa T, Ito Y, Nagai T, Isotani H, Iwata Y, Yamamoto K, Fujimoto S, Seishu S, Fukushima Y et al. 2001 GATA3 abnormalities and the phenotypic spectrum of HDR syndrome. Journal of Medical Genetics 38 374-380. (doi:10.1136/jmg.38.6.374)

Nakayama K, Ishida N, Shirane M, Inomata A, Inoue T, Shishido N, Horii I \& Loh DY 1996 Mice lacking p27(Kip1) display increased body size, multiple organ hyperplasia, retinal dysplasia, and pituitary tumors. Cell 85 707-720. (doi:10.1016/S0092-8674(00)81237-4)

Nesbit MA, Bowl MR, Harding B, Ali A, Ayala A, Crowe C, Dobbie A, Hampson G, Holdaway I, Levine MA et al. 2004 Characterization of GATA3 mutations in the hypoparathyroidism, deafness, and renal dysplasia (HDR) syndrome. Journal of Biological Chemistry 279 22624-22634. (doi:10. 1074/jbc.M401797200)

Newey PJ, Bowl MR \& Thakker RV 2009 Parafibromin - functional insights. Journal of Internal Medicine 266 84-98. (doi:10.1111/j.1365-2796.2009. 02107.x)

Newey PJ, Bowl MR, Cranston T \& Thakker RV 2010 Cell division cycle protein 73 homolog (CDC73) mutations in the hyperparathyroidism-jaw tumor syndrome (HPT-JT) and parathyroid tumors. Human Mutation 31 295-307. (doi:10.1002/humu.21188)

Nguyen D \& Xu T 2008 The expanding role of mouse genetics for understanding human biology and disease. Disease Models and Mechanisms $\mathbf{1}$ $56-66$.

Norum RA, Lafreniere RG, O'Neal LW, Nikolai TF, Delaney JP, Sisson JC, Sobol H, Lenoir GM, Ponder BA, Willard HF et al. 1990 Linkage of the multiple endocrine neoplasia type $2 \mathrm{~B}$ gene (MEN2B) to chromosome 10 markers linked to MEN2A. Genomics 8 313-317. (doi:10.1016/08887543(90)90287-5) 
Ozawa A, Agarwal SK, Mateo CM, Burns AL, Rice TS, Kennedy PA, Quigley CM, Simonds WF, Weinstein LS, Chandrasekharappa SC et al. 2007 The parathyroid/pituitary variant of multiple endocrine neoplasia type 1 usually has causes other than p27Kip1 mutations. Journal of Clinical Endocrinology and Metabolism 92 1948-1951. (doi:10.1210/jc.2006-2563)

Pandolfi PP, Roth ME, Karis A, Leonard MW, Dzierzak E, Grosveld FG, Engel JD \& Lindenbaum MH 1995 Targeted disruption of the GATA3 gene causes severe abnormalities in the nervous system and in fetal liver haematopoiesis. Nature Genetics 11 40-44. (doi:10.1038/ng0995-40)

Pearce SH, Williamson C, Kifor O, Bai M, Coulthard MG, Davies M, LewisBarned N, McCredie D, Powell H, Kendall-Taylor P et al. 1996 A familial syndrome of hypocalcemia with hypercalciuria due to mutations in the calcium-sensing receptor. New England Journal of Medicine 335 1115-1122. (doi:10.1056/NEJM199610103351505)

Pellegata NS, Quintanilla-Martinez L, Siggelkow H, Samson E, Bink K, Hofler H, Fend F, Graw J \& Atkinson MJ 2006 Germ-line mutations in p27Kip1 cause a multiple endocrine neoplasia syndrome in rats and humans. PNAS 103 15558-15563. (doi:10.1073/pnas.0603877103)

Piotrowska K, Pellegata NS, Rosemann M, Fritz A, Graw J \& Atkinson MJ 2004 Mapping of a novel MEN-like syndrome locus to rat chromosome 4. Mammalian Genome 15 135-141. (doi:10.1007/s00335-003-3027-8)

Pollak MR, Brown EM, Chou YH, Hebert SC, Marx SJ, Steinmann B, Levi T, Seidman CE \& Seidman JG 1993 Mutations in the human Ca(2+)sensing receptor gene cause familial hypocalciuric hypercalcemia and neonatal severe hyperparathyroidism. Cell 75 1297-1303. (doi:10.1016/ 0092-8674(93)90617-Y)

Pollak MR, Brown EM, Estep HL, McLaine PN, Kifor O, Park J, Hebert SC, Seidman CE \& Seidman JG 1994 Autosomal dominant hypocalcaemia caused by a $\mathrm{Ca}(2+)$-sensing receptor gene mutation. Nature Genetics $\mathbf{8}$ 303-307. (doi:10.1038/ng1194-303)

Quwailid MM, Hugill A, Dear N, Vizor L, Wells S, Horner E, Fuller S, Weedon J, McMath H, Woodman P et al. 2004 A gene-driven ENU-based approach to generating an allelic series in any gene. Mammalian Genome $\mathbf{1 5}$ 585-591. (doi:10.1007/s00335-004-2379-z)

Raid R, Krinka D, Bakhoff L, Abdelwahid E, Jokinen E, Karner M, Malva M, Meier R, Pelliniemi LJ, Ploom M et al. 2009 Lack of Gata3 results in conotruncal heart anomalies in mouse. Mechanisms of Development $\mathbf{1 2 6}$ 80-89. (doi:10.1016/j.mod.2008.10.001)

Reynolds L, Jones K, Winton DJ, Cranston A, Houghton C, Howard L, Ponder BA \& Smith DP 2001 C-cell and thyroid epithelial tumours and altered follicular development in transgenic mice expressing the long isoform of MEN 2A RET. Oncogene 20 3986-3994. (doi:10.1038/sj.onc. 1204434)

Rodriguez L, Tu C, Cheng Z, Chen TH, Bikle D, Shoback D \& Chang W 2005 Expression and functional assessment of an alternatively spliced extracellular $\mathrm{Ca}^{2+}$-sensing receptor in growth plate chondrocytes. Endocrinology 146 5294-5303. (doi:10.1210/en.2005-0256)

Rozenblatt-Rosen O, Hughes CM, Nannepaga SJ, Shanmugam KS, Copeland TD, Guszczynski T, Resau JH \& Meyerson M 2005 The parafibromin tumor suppressor protein is part of a human Paf1 complex. Molecular and Cellular Biology 25 612-620. (doi:10.1128/MCB.25.2.612620.2005)

Runeberg-Roos P \& Saarma M 2007 Neurotrophic factor receptor RET: structure, cell biology, and inherited diseases. Annals of Medicine 39 572-580. (doi:10.1080/07853890701646256)

Scacheri PC, Crabtree JS, Novotny EA, Garrett-Beal L, Chen A, Edgemon KA, Marx SJ, Spiegel AM, Chandrasekharappa SC \& Collins FS 2001 Bidirectional transcriptional activity of PGK-neomycin and unexpected embryonic lethality in heterozygote chimeric knockout mice. Genesis $\mathbf{3 0}$ 259-263. (doi:10.1002/gene.1072)

Scacheri PC, Crabtree JS, Kennedy AL, Swain GP, Ward JM, Marx SJ, Spiegel AM \& Collins FS 2004a Homozygous loss of menin is well tolerated in liver, a tissue not affected in MEN1. Mammalian Genome 15 872-877. (doi:10.1007/s00335-004-2395-z)

Scacheri PC, Kennedy AL, Chin K, Miller MT, Hodgson JG, Gray JW, Marx SJ, Spiegel AM \& Collins FS 2004b Pancreatic insulinomas in multiple endocrine neoplasia, type I knockout mice can develop in the absence of chromosome instability or microsatellite instability. Cancer Research 64 7039-7044. (doi:10.1158/0008-5472. CAN-04-1648)

Shen HC, Rosen JE, Yang LM, Savage SA, Burns AL, Mateo CM, Agarwal SK, Chandrasekharappa SC, Spiegel AM, Collins FS et al. 2008 Parathyroid tumor development involves deregulation of homeobox genes. EndocrineRelated Cancer 15 267-275. (doi:10.1677/ERC-07-0191)

Shen HC, He M, Powell A, Adem A, Lorang D, Heller C, Grover AC, Ylaya K, Hewitt SM, Marx SJ et al. 2009 Recapitulation of pancreatic neuroendocrine tumors in human multiple endocrine neoplasia type I syndrome via Pdx1-directed inactivation of Men1. Cancer Research 69 1858-1866. (doi:10.1158/0008-5472.CAN-08-3662)

Shen HC, Ylaya K, Pechhold K, Wilson A, Adem A, Hewitt SM \& Libutti SK 2010 Multiple endocrine neoplasia type 1 deletion in pancreatic alpha-cells leads to development of insulinomas in mice. Endocrinology 151 4024-4030. (doi:10.1210/en.2009-1251)

Simpson NE, Kidd KK, Goodfellow PJ, McDermid H, Myers S, Kidd JR, Jackson CE, Duncan AM, Farrer LA, Brasch K et al. 1987 Assignment of multiple endocrine neoplasia type $2 \mathrm{~A}$ to chromosome 10 by linkage. Nature 328 528-530. (doi:10.1038/328528a)

Smith-Hicks CL, Sizer KC, Powers JF, Tischler AS \& Costantini F 2000 C-cell hyperplasia, pheochromocytoma and sympathoadrenal malformation in a mouse model of multiple endocrine neoplasia type $2 \mathrm{~B}$. EMBO Journal 19 612-622. (doi:10.1093/emboj/19.4.612)

Stanford WL, Cohn JB \& Cordes SP 2001 Gene-trap mutagenesis: past, present and beyond. Nature Reviews. Genetics 2 756-768. (doi:10.1038/35093548)

Strom TM, Francis F, Lorenz B, Boddrich A, Econs MJ, Lehrach H \& Meitinger T 1997 Pex gene deletions in Gy and Hyp mice provide mouse models for X-linked hypophosphatemia. Human Molecular Genetics 6 165-171.

Sweetser DA, Froelick GJ, Matsumoto AM, Kafer KE, Marck B, Palmiter RD \& Kapur RP 1999 Ganglioneuromas and renal anomalies are induced by activated RET(MEN2B) in transgenic mice. Oncogene 18 877-886. (doi:10. 1038/sj.onc.1202376)

Szabo J, Heath B, Hill VM, Jackson CE, Zarbo RJ, Mallette LE, Chew SL, Besser GM, Thakker RV, Huff V et al. 1995 Hereditary hyperparathyroidismjaw tumor syndrome: the endocrine tumor gene HRPT2 maps to chromosome 1q21-q31. American Journal of Human Genetics 56 944-950.

Teh BT, Farnebo F, Kristoffersson U, Sundelin B, Cardinal J, Axelson R, Yap A, Epstein M, Heath H III, Cameron D et al. 1996 Autosomal dominant primary hyperparathyroidism and jaw tumor syndrome associated with renal hamartomas and cystic kidney disease: linkage to 1q21-q32 and loss of the wild type allele in renal hamartomas. Journal of Clinical Endocrinology and Metabolism 81 4204-4211. (doi:10.1210/jc.81.12.4204)

Teh BT, Farnebo F, Twigg S, Hoog A, Kytola S, Korpi-Hyovalti E, Wong FK, Nordenstrom J, Grimelius L, Sandelin K et al. 1998 Familial isolated hyperparathyroidism maps to the hyperparathyroidism-jaw tumor locus in 1q21-q32 in a subset of families. Journal of Clinical Endocrinology and Metabolism 83 2114-2120. (doi:10.1210/jc.83.6.2114)

Tenenhouse HS 1999 X-linked hypophosphataemia: a homologous disorder in humans and mice. Nephrology, Dialysis, Transplantation 14 333-341. (doi:10.1093/ndt/14.2.333)

Thakker RV 2004 Diseases associated with the extracellular calcium-sensing receptor. Cell Calcium 35 275-282. (doi:10.1016/j.ceca.2003.10.010)

Thakker RV 2006 Multiple endocrine neoplasia type 1. In Endocrinology, 5th edn, pp 3509-3531. Eds LJ DeGroot \& JL Jameson. Philadelphia: Elsevier Saunders.

Thakker RV 2010 Multiple endocrine neoplasia type 1 (MEN1). Best Practice and Research. Clinical Endocrinology and Metabolism 24 355-370. (doi:10. 1016/j.beem.2010.07.003)

Thakker RV, Bouloux P, Wooding C, Chotai K, Broad PM, Spurr NK, Besser GM \& O'Riordan JL 1989 Association of parathyroid tumors in multiple endocrine neoplasia type 1 with loss of alleles on chromosome 11. New England Journal of Medicine 321 218-224. (doi:10.1056/NEJM198907 273210403)

Trump D, Farren B, Wooding C, Pang JT, Besser GM, Buchanan KD, Edwards CR, Heath DA, Jackson CE, Jansen S et al. 1996 Clinical studies of multiple endocrine neoplasia type 1 (MEN1). Quarterly Journal of Medicine 89 653-669. 
Tu Q, Pi M, Karsenty G, Simpson L, Liu S \& Quarles LD 2003 Rescue of the skeletal phenotype in CasR-deficient mice by transfer onto the Gcm2 null background. Journal of Clinical Investigation 111 1029-1037. (doi:10.1172/JCI17054)

Van Esch H, Groenen P, Nesbit MA, Schuffenhauer S, Lichtner P, Vanderlinden G, Harding B, Beetz R, Bilous RW, Holdaway I et al. 2000 GATA3 haplo-insufficiency causes human HDR syndrome. Nature 406 419-422. (doi:10.1038/35019088)

Vargas-Poussou R, Huang C, Hulin P, Houillier P, Jeunemaitre X, Paillard M, Planelles G, Dechaux M, Miller RT \& Antignac C 2002 Functional characterization of a calcium-sensing receptor mutation in severe autosomal dominant hypocalcemia with a Bartter-like syndrome. Journal of the American Society of Nephrology 13 2259-2266. (doi:10.1097/01.ASN. $0000025781.16723 .68)$

Vitelli F, Morishima M, Taddei I, Lindsay EA \& Baldini A 2002 Tbx1 mutation causes multiple cardiovascular defects and disrupts neural crest and cranial nerve migratory pathways. Human Molecular Genetics 11 915-922. (doi:10.1093/hmg/11.8.915)

Walls GV, Bowl MR, Jeyabalan J, Reed AA, Harding B, Ali A, Bradley KJ, Wang P, Chen J, Williams BO et al. 2009 Mice deleted for the hyperparathyroidism-jaw tumour (HPT-JT) syndrome allele have abnormal parathyroids with increased proliferation rates. Endocrine Abstracts 19 OC30.

Wang P, Bowl MR, Bender S, Peng J, Farber L, Chen J, Ali A, Zhang Z, Alberts AS, Thakker RV et al. 2008 Parafibromin, a component of the human PAF complex, regulates growth factors and is required for embryonic development and survival in adult mice. Molecular and Cellular Biology 28 2930-2940. (doi:10.1128/MCB.00654-07)

Watanabe S, Fukumoto S, Chang H, Takeuchi Y, Hasegawa Y, Okazaki R, Chikatsu N \& Fujita T 2002 Association between activating mutations of calcium-sensing receptor and Bartter's syndrome. Lancet 360 692-694. (doi:10.1016/S0140-6736(02)09842-2)
Waterston RH, Lindblad-Toh K, Birney E, Rogers J, Abril JF, Agarwal P, Agarwala R, Ainscough R, Alexandersson M, An P et al. 2002 Initial sequencing and comparative analysis of the mouse genome. Nature $\mathbf{4 2 0}$ 520-562. (doi:10.1038/nature01262)

van der Wees J, van Looij MA, de Ruiter MM, Elias H, van der Burg H, Liem SS, Kurek D, Engel JD, Karis A, van Zanten BG et al. 2004 Hearing loss following Gata3 haploinsufficiency is caused by cochlear disorder. Neurobiology of Disease 16 169-178. (doi:10.1016/j.nbd.2004.02.004)

Wohllk N, Schweizer H, Erlic Z, Schmid KW, Walz MK, Raue F \& Neumann HP 2010 Multiple endocrine neoplasia type 2. Best Practice and Research. Clinical Endocrinology and Metabolism 24 371-387. (doi:10.1016/ j.beem.2010.02.001)

Yagi H, Furutani Y, Hamada H, Sasaki T, Asakawa S, Minoshima S, Ichida F, Joo K, Kimura M, Imamura S et al. 2003 Role of TBX1 in human del22q11.2 syndrome. Lancet 362 1366-1373. (doi:10.1016/S01406736(03)14632-6)

Yin L, Puliti A, Bonora E, Evangelisti C, Conti V, Tong WM, Medard JJ, Lavoue MF, Forey N, Wang LC et al. 2007 C620R mutation of the murine ret proto-oncogene: loss of function effect in homozygotes and possible gain of function effect in heterozygotes. International Journal of Cancer 121 292-300. (doi:10.1002/ijc.22378)

Zhang Z, Huynh T \& Baldini A 2006 Mesodermal expression of Tbx1 is necessary and sufficient for pharyngeal arch and cardiac outflow tract development. Development 133 3587-3595. (doi:10.1242/ dev.02539)

Received in final form 24 June 2011

Accepted 15 July 2011

Made available online as an Accepted Preprint 15 July 2011 